\title{
13. BOREHOLE FLUID CHEMISTRY IN HOLE 504B, LEG 137: FORMATION WATER OR IN-SITU REACTION? ${ }^{1}$
}

\author{
Andrew J. Magenheim, ${ }^{2}$ Arthur J. Spivack, ${ }^{2}$ Jeffrey C. Alt ${ }^{3}$ Gregory Bayhurst, ${ }^{4}$ L.-H. Chan, ${ }^{5}$ \\ Evelyn Zuleger, ${ }^{6}$ and Joris M. Gieskes ${ }^{2}$
}

\begin{abstract}
Circulation of seawater through basaltic basement for several million years after crustal emplacement has been inferred from studies of surface heat flow, and may play a significant role in the exchange of elements between the oceanic crust and seawater. Without direct observation of the fluid chemistry, interpretations regarding the extent and timing of this exchange must be based on the integrated signal of alteration found in sampled basalts. Much interest has thus been expressed in obtaining and analyzing fluids directly from basaltic formations.

It has been proposed that open oceanic boreholes can be used as oceanic groundwater wells to obtain fluids that are circulating within the formation. Water samples were collected from the open borehole in Hole 504B prior to drilling operations on Leg 137, with the original intention of collecting formation fluids from the surrounding basaltic rocks. Past results have yielded ambiguous conclusions as to the origin of the fluids recovered-specifically, whether or not the fluids were true formation fluids or merely the result of reaction of seawater in the borehole environment.

The chemistry of eight borehole fluid samples collected during Leg 137 is discussed in this paper. Large changes in major, minor, and isotopic compositions relative to unaltered seawater were observed in the borehole fluids. Compositional changes increased with depth in the borehole. The samples exhibit the effect of simple mixing of seawater, throughout the borehole, with a single reacted fluid component. Analysis and interpretation of the results from Leg 137 in light of past results suggest that the chemical signals observed may originate predominantly from reaction with basaltic rubble residing at the bottom of the hole during the interim between drilling legs. Although this endeavor apparently did not recover formation waters, information on the nature of reaction between seawater and basalt at the prevalent temperatures in Hole $504 \mathrm{~B}\left(\geq 160^{\circ} \mathrm{C}\right)$ has been gained that can be related to reconstruction of the alteration history of the oceanic crust. Isotopic analyses allow calculation of element-specific water/rock mass ratios ( $\mathrm{Li}$ and $\mathrm{Sr}$ ) and are related to the extent of chemical exchange between the borehole fluids and basalt.
\end{abstract}

\section{INTRODUCTION}

One of the most elusive questions regarding the alteration history of the oceanic crust is the degree and timing of alteration that occurs on the ridge flank due to reaction with circulating fluids. Direct observations of high temperature $\left(250^{\circ} \mathrm{C}-400^{\circ} \mathrm{C}\right)$ axial hydrothermal activity are documented at many ridge crests around the globe (e.g., Von Damm, 1990). The effects of low temperature weathering of the basaltic crust by seawater over tens of millions of years have been documented by observation of dredged and drilled basalts from the shallower sections of the ocean crust (e.g,. Staudigel and Hart, 1983; Alt and Honnorez, 1984; Böhlke et al., 1980). However, relatively little is known about the extent of alteration in the moderate temperature regimes $\left(75^{\circ} \mathrm{C}-250^{\circ} \mathrm{C}\right)$ of ridge flank environments and hydrothermal recharge zones, where circulation of fluids is inferred from heat flow anomalies (e.g., Anderson et al., 1977).

Circulation of seawater in the ridge flank area near Hole 504B has been documented by Langseth et al. (1988), and modeled by Fisher et al. (1990). Drill core samples from Hole 504B provide direct evidence for seawater alteration at temperatures below about $350^{\circ} \mathrm{C}$ (cf., Alt et al., 1986). The presence of anhydrite, zeolites, and some clays reflects alteration temperatures in the moderate $150^{\circ} \mathrm{C}-250^{\circ} \mathrm{C}$ temperature range, similar to the current crustal temperatures at the bottom of Hole

'Erzinger, J., Becker, K., Dick, H.J.B., and Stokking, L.B. (Eds.), 1995, Proc. ODP Sci. Results, 137/140: College Station, TX (Ocean Drilling Program).

${ }^{2}$ Scripps Institution of Oceanography, La Jolla, CA 92093-0208, U.S.A.

${ }^{3}$ Department of Geological Sciences, University of Michigan, Ann Arbor, MI 48109 1063, U.S.A.

${ }_{4}^{4}$ Los Alamos National Laboratory, Los Alamos. NM 87545, U.S.A.

${ }^{5}$ Department of Geology and Geophysics, Louisiana State University, Baton Rouge, LA 70803, U.S.A.

${ }^{6}$ Institut für Geowissenschaften und Lithosphărenforschung, Justus-Liebig-Universität, D-6300 Senckenbergstraße 3, Federal Republic of Germany.
504B. At present it is unclear whether significant elemental fluxes between seawater and the ocean can occur in these off-axial hydrothermal environments. Attempts to locate sites of off-axis hydrothermal discharge to elucidate elemental fluxes have been disappointing (Baker et al., 1991; Hess et al., 1991).

In principle, fluids circulating within Layer 2 can be sampled from open-oceanic boreholes, in a manner analogous to that of groundwater wells on land. However, this task has proven to be quite difficult as water depth, sampler deployment, temperature gradients, and drilling strategies all inhibit success of these endeavors. Mottl and Gieskes (1990) provide a review of the various attempts and strategies to sample fluids from open boreholes. Sampling strategies can be divided into two categories: active and passive. Active mode sampling requires that a sampler is sealed in the borehole annulus or wall, and fluid is actively extracted from the formation using a pressure gradient (Mottl and Gieskes, 1990). Whereas some degree of success has been achieved in sedimentary formations using the Barnes-Uyeda Tool and prototypes, attempts to actively withdraw fluids from basaltic formations have not succeeded. In the passive sampling mode, the borehole is left open and undisturbed by drilling operations for an extended period of time (several years), allowing formation fluids to exchange with the borehole fluids. Exchange could result from either direct flow into the borehole by advection through a fracture or fractures, or slower diffusive exchange (Mottl and Gieskes, 1990). Advective introduction of the formation fluids into the open borehole in Hole 534A along a sedimentary fracture has been demonstrated by Gieskes and Magenheim (1992). The passive mode has been the only successful sampling strategy to date in basaltic basement, but the origin of the reacted fluids is still in question.

Hole 504B has received the greatest effort toward obtaining formation fluids by sampling the open borehole. Samples have been obtained during six Deep Sea Drilling Project/Ocean Drilling Program (DSDP/ ODP) expeditions as outlined in Table 1 . The times between drilling 
Table 1. Summary of borehole fluid sampling attempts at Hole 504B.

\begin{tabular}{rccr}
\hline $\begin{array}{c}\text { Drilling } \\
\text { leg }\end{array}$ & $\begin{array}{c}\text { Maximum } \\
\text { depth (mbsf) }\end{array}$ & $\begin{array}{c}\text { Maximum } \\
\text { temperature }\left({ }^{\circ} \mathrm{C}\right)\end{array}$ & $\begin{array}{l}\text { Time. } \\
(\text { days })\end{array}$ \\
\hline 70 & 489 & 80 & 39 \\
83 & 836 & 112 & 711 \\
92 & 1350 & 145 & 470 \\
111 & 1350 & 145 & 1233 \\
137 & 1562 & 162 & 1633 \\
\hline
\end{tabular}

Notes: Time is the time interval between the end of drilling operations on the previous leg and borehole fluid sampling on the leg of interest. The maximum borehole depth and maximum temperatures are before drilling operations on the leg of interest.

legs, borehole depths, and maximum borehole temperatures were variable for each of these visits as the hole was deepened (Table 1). Attempts to deploy active samplers were not successful and resulted in collection of fluid from the borehole itself, and thus collected "passive" type samples. Changes in fluid chemistry relative to normal seawater composition have been observed during each attempt to collect borehole fluids, suggesting interaction with the basaltic basement (Mottl and Gieskes, 1990). The fluids reveal a two-component mixture between seawater and a reacted fluid component. In principle, this could be due to either a component of true formation fluid or reaction within the borehole itself. In addition, downhole mixing of bottom seawater into the open borehole has been inferred (Mottl and Gieskes, 1990).

Mottl et al. (1985) and Mottl and Gieskes (1990) provide support for the concept of molecular diffusion of formation water into the borehole through the wall rocks. This argument is based on the use of tritium concentrations to trace the original surface seawater placed in the borehole at the end of drilling operations on previous legs. In the Pacific Ocean, tritium is only present in surface waters, and therefore, it provides a definitive tracer for the original fluid left in the hole. Displacement with either deep water or formation fluids would result in a decreased concentration of tritium in the borehole. Mottl and Gieskes (1990) calculated that molecular diffusion can supply a component (as much as $30 \%$ ) of formation fluid to the borehole. One of the major objectives of the borehole water sampling program for Leg 137 was to attempt to answer the question of whether formation fluid was actually recovered from the borehole, or whether reaction in the borehole environment is responsible for the observed chemical changes.

Elemental abundances and isotopic compositions were determined for fluids obtained during Leg 137 from the open borehole at Hole 504B. This information is used to elucidate the origin of the reacted fluid component present in the borehole. In addition, analyses of anhydrite crusts, and basaltic rubble, collected from the bottom of Hole $504 \mathrm{~B}$ prior to drilling on Leg 137 , are presented. Information regarding the nature of elemental exchange between seawater and the basaltic crust in the temperature range of the borehole is discussed in light of the observed chemistry of the borehole samples from this and prior expeditions.

\section{METHODS}

\section{Shipboard Operations}

Shipboard operations are described in detail in the Leg 137 Initial Reports (Shipboard Scientific Party, 1992a). At the end of Leg 111 in 1985 several volumes of surface seawater were flushed through the borehole to remove drilling mud and debris (Shipboard Scientific Party, 1988). The borehole remained undisturbed for 1633 days until reoccupation of the site during Leg 137 in 1991. Fluid sampling was conducted before any drilling operations, and the drill string was lowered only $50 \mathrm{~m}$ into the casing to avoid any disturbance to the borehole fluids. Samples were collected using two flow-through type samplers: a modified Leutert sampling tool (from the Los Alamos National Laboratories) activated by a mechanical clock, and a tool from the Lawrence Berkeley Laboratories (LBL) triggered through the logging cable. The samplers were lowered into the hole and slowed to a stop $100 \mathrm{~m}$ above the desired sampling location. Every effort was made to provide undisturbed samples, but as indicated by the Leg 137 Shipboard Scientific Party (1992a) some dilution was evident. Sampling artifacts can come from two potential sources: disturbance of the borehole fluid column resulting in downhole mixing, or leakage of the samplers, often as a result of shrinkage upon recovery of the sample. The latter problem was checked by recording the mass of fluid recovered and comparing it to the expected mass based on the temperature and pressure of the samples at the intended sampling depth. Detailed analysis of the mass of sample recovered indicated that all the samples were subject to some leakage as the recovered mass was greater than the mass expected for the volume of the sampler (Shipboard Scientific Party, 1992a). This internal overpressure created some problems during removal of samples as it prevented normal operation of the sample extraction device on the Los Alamos tool. In particular, the first sample, from 350 mbsf, was exposed to the atmosphere because of the need to completely dismantle the sampler to remove the sample. Exposure to atmospheric oxygen was unavoidable, resulting in a large amount of orange iron oxyhydroxide precipitation prior to filtration. This problem was avoided in subsequent samples (details are given in Shipboard Scientific Party, 1992a). Despite these sampling difficulties, much useful information can be extracted from the sample data as the dilutant, seawater, is the same for all samples (see following discussion). Extraction and preservation of the samples is described in detail in Shipboard Scientific Party (1992a).

Because the primary goals of Leg 137 were to remove a diamond core bit left behind from Leg 111 and to clean the borehole for future drilling, we were able to collect material that resided at the bottom of the borehole during the 1633-day interim between the end of Leg 111 and Leg 137. This material included $\mathrm{cm}$-sized pieces of anhydrite crust, which apparently precipitated directly from the borehole fluids (Shipboard Scientific Party, 1992a, fig. 21). Also, pieces of basaltic rubble from the hole bottom were examined for evidence of reaction with the borehole fluids. All pieces examined were taken from the first junk basket deployment and were recovered before any drilling or milling operations. Many of the pieces of basaltic rubble were worn with rounded edges, suggesting some degree of mechanical disturbance in the past, probably caused by bit recovery attempts at the end of Leg 111.

\section{Analytical Methods}

Many of the fluid analyses were performed within hours to days by standard methodology aboard the JOIDES Resolution. A brief summary of the methods, including analytical errors $(2 \sigma)$, is given in Table 2 .

Sulfur isotopic measurements of dissolved sulfate were performed by first precipitating the seawater sulfate as $\mathrm{BaSO}_{4}$, which was then combusted with sodium metaphosphate at $1000^{\circ} \mathrm{C}$. Evolved $\mathrm{SO}_{2}$ gas was analyzed on a VG 602 Mass Spectrometer. Isotopic results are presented in per mil deviation, as $\delta^{34} \mathrm{~S}(\%)$, relative to Canyon Diablo Triolite (CDT). Since $\mathrm{H}_{2} \mathrm{~S}$ was below detectable limits, the values for $\delta^{34} \mathrm{~S}$ are considered to be unaffected by sulfide oxidation.

Boron concentrations were determined by isotope dilution (ID) mass spectroscopy. Boron isotopic compositions (for selected samples) were determined using the positive ion thermal ionization mass spectrometry (TIMS) technique of Spivack and Edmond (1986), after purifying the boron following the procedures of Nakamura et al. (1992). Isotopic ratios are determined by TIMS of the $\mathrm{Cs}_{2} \mathrm{BO}_{2}^{+}$molecular ion on a VG 336 mass spectrometer. Boron isotopic compositions are reported as per mil deviations, $\delta^{\prime \prime} \mathrm{B}(\%)$, relative to measured values of the NBS 951 standard. The measured ratio for NBS 951 is 4.0552

$\mathrm{Sr}$ isotope ratios were determined by dynamic multicollection TIMS on a VG 336 mass spectrometer. The $\mathrm{Sr}$ was first separated on ion exchange resin columns using standard techniques and then loaded onto a W filament. Measured ratios of ${ }^{87} \mathrm{Sr} /{ }^{86} \mathrm{Sr}$ were normal- 
ized to ${ }^{86} \mathrm{Sr} /{ }^{88} \mathrm{Sr}=0.1194$ using an exponential law correction. Using this procedure, the standard NBS 987 yielded an isotopic composition of $0.710283 \pm 0.000012(2 \sigma, \mathrm{n}=9)$. The measured data have been normalized to the accepted value of NBS $987\left({ }^{87} \mathrm{Sr} /{ }^{86} \mathrm{Sr}=0.710250\right)$. This procedure produces a very small correction, but is performed for comparative purposes. Measured values for IAPSO Standard Seawater $(0.709232, n=5)$ result in the accepted value for contemporaneous seawater of 0.709199 after this correction is applied.

$\mathrm{Li}$ isotope ratios were determined using dynamic multicollection TIMS. The Li was first separated using cation exchange chromatography as in Chan and Edmond (1988). The isotopic ratios were determined on the $\mathrm{LiNaBO}_{2}^{+}$molecular ion (Chan et al., 1992). $\mathrm{Li}$ isotope ratios are reported as per mil deviations $(\%)$ from the NBS isotope standard (L-SVEC), in which the $\mathrm{Li}$ isotope ratio was determined to be ${ }^{6} \mathrm{Li} /{ }^{7} \mathrm{Li}=0.083062 \pm 0.00054$ (Chan et al., 1992).

The rare earth element (REE) concentrations were determined by inductively coupled plasma-mass spectrometry (ICP-MS) after preconcentration using the chromatographic techniques of Zuleger and Erzinger (1988).

Analyses were also made of the anhydrite crusts. The anhydrite was first washed and then leached with water, to avoid dissolving any contaminants in the anhydrite. $\mathrm{Sr}$ and $\mathrm{Ca}$ were measured on the leach solutions by flame atomic absorption as were the borehole fluids. $\mathrm{Sr}$ isotopic compositions were measured by the same technique employed for the borehole fluids (Table 2).

\section{RESULTS AND DISCUSSION}

\section{General Observations}

The results of chemical analyses performed on the borehole fluids are presented in Table 3, and downhole profiles for the various chemical species are given in Figure 1. The data from Sample $137504 \mathrm{~B}$ BB-004 are not included in the profiles as this sample contained fluid with a composition close to that of seawater, and is thought to have leaked or pre-tripped (Shipboard Scientific Party, 1992a). Anumber of downhole trends are clear: $\mathrm{pH}$, alkalinity, $\mathrm{Mg}, \mathrm{SO}_{4}, \mathrm{Na}, \mathrm{K}, \mathrm{Sr}$, and $\mathrm{Rb}$ decrease with depth in the borehole; while $\mathrm{Cl}, \mathrm{Ca}, \mathrm{H}_{4} \mathrm{SiO}_{4}, \mathrm{Li}, \mathrm{Mn}$, and $\mathrm{Ba}$ increase with depth. Some scatter from the drawn profile lines is apparent, particularly for the samples from 1400 and $1550 \mathrm{mbsf}$. This scatter is presumed to be due to sampling artifacts resulting from either downhole mixing from repeated running of the samplers into the borehole, entrainment of fluid in the interior of the samplers, or leaking of the sampler during recovery. The sources of potential sampling artifacts are discussed in detail by the Shipboard Scientific Party (1992a).

These trends are in general agreement with results of experimental simulations of seawater/basalt interactions at the in-situ temperatures $\left(80^{\circ}-150^{\circ} \mathrm{C}\right)$. One significant exception is the decrease in Na concentration in the borehole fluids, as $\mathrm{Na}$ is usually constant or rises during the experimental simulations in this temperature range (Seyfried and Bischoff, 1979). Charge balance calculations indicate that the increase in $\mathrm{Ca}$ is nearly balanced by decreases in $\mathrm{Na}$ and $\mathrm{Mg}$. This situation suggests exchange of $\mathrm{Na}$ and $\mathrm{Mg}$ from seawater for Ca during reaction of seawater and basalt. Increases in $\mathrm{Cl}$ concentration with depth are consistent with the precipitation of hydrous clay minerals.

To evaluate the relative changes in the borehole fluid chemistry without the potential sampling artifacts, particularly dilution with seawater upon ascent, the data are presented in element vs. element diagrams in Figure 2. The data are presented relative to $\mathrm{Mg}$ for consistency and similarity to studies of ridge crest hydrothermal fluids. $\mathrm{Mg}$ is chosen as it is known to be removed from seawater at all temperatures during reaction with basalt. This format for data presentation provides a basis to establish mixing trends and the degree of enrichment or depletion of elements with respect to each other. For most elements, the data fall on remarkably linear trends, including samples from 1440 and 1500 mbsf (Fig. 2A-L). The lines intersect near the composition of seawater, indicating that it is one endmember of the two-component mixture. The other endmember lies along the
Table 2. Summary of analytical methods for the borehole fluids.

\begin{tabular}{|c|c|c|c|}
\hline Analyte & Method & Error & Reference \\
\hline Alkalinity, pH & $\mathrm{pH}$ electrode, alkalinity titration & $5 \%$ & 1 \\
\hline Salinity & Goldberg Refractometer & & 1 \\
\hline $\mathrm{Cl}^{-}$ & Potentiometric titration & $0.5 \%$ & 2 \\
\hline $\mathrm{SO}_{4}^{2-}$ & Dionex ion chromotography & $2.0 \%$ & 1 \\
\hline $\mathrm{Ca}^{2+}$ & EGTA titration & $1.0 \%$ & 1 \\
\hline $\mathrm{Mg}^{2+}$ & EDTA titration & $2.0 \%$ & 1 \\
\hline $\begin{array}{l}\mathrm{NH}_{4}^{+}, \mathrm{NO}_{3}^{-}, \\
\mathrm{H}_{4} \mathrm{SiO}_{4}, \mathrm{PO}_{4}^{3-} \\
\mathrm{Br}^{-}, \mathrm{I}^{-}, \mathrm{H}_{2} \mathrm{~S}\end{array}$ & Standard colorimetric techs. & Varies & 3 \\
\hline $\mathrm{K}^{+}, \mathrm{Na}^{+}$ & Flame AES & $2.0 \%$ & 1 \\
\hline $\mathrm{Li}^{+}$ & Flame AES & $3.0 \%$ & 1 \\
\hline $\mathrm{Sr}^{2+}, \mathrm{Fe}$ & Flame AAS & $3.0 \%$ & 1 \\
\hline Mn & Flameless AAS & $2.0 \%$ & 4 \\
\hline $\mathrm{Ba}, \mathrm{Rb}$ & ICP M.S., standard additions & $\leq 2.0 \%$ & \\
\hline REE & ICP MS & $<10 \%$ & 5,6 \\
\hline B & Isotope dilution & $<1.0 \%$ & \\
\hline$\delta^{11} \mathrm{~B}$ (NBS 951) & TIMS & $0.5 \%$ & 7 \\
\hline${ }^{87} \mathrm{Sr}{ }^{86} \mathrm{Sr}$ & TIMS & $20 \times 10^{-6}$ & \\
\hline$\delta^{34} \mathrm{~S}(\mathrm{CDT})$ & $\mathrm{SO}_{2}$ gas MS & $0.4 \%$ & \\
\hline$\delta^{6} \mathrm{Li}$ (L-SVEC) & TIMS & $0.8 \%$ & 8 \\
\hline$\delta^{18} \mathrm{O}$ (SMOW) & M.S. & & \\
\hline SD (SMOW) & M.S. & & \\
\hline$\delta^{13} \mathrm{C}(\mathrm{PDB})$ & M.S. & & \\
\hline
\end{tabular}

Notes: Errors reported as 2 times the standard deviation. References: $1=$ Gieskes et al. (1991); 2 = Gieskes and Peretsman (1986): 3 = Shipboard Scientific Party (1992a); 4 = Magenheim (1989); 5 = Zuleger and Erzinger (1988); 6 = Totland et al. (1992); $7=$ Ishikawa and Nakamura (1992); $8=$ Chan (1987).

line somewhere beyond the lowest $\mathrm{Mg}$ concentration, and will be referred to as the reacted fluid endmember. Two conclusions are clear from the linear elemental mixing trends: (1) samples that fall off the general downhole trends (Fig. 1) are most likely the result of sampling artifacts, and (2) mixing of seawater with a reacted fluid component occurs in the borehole.

Figure $2 \mathrm{M}-\mathrm{O}$ shows elements that do not display simple mixing trends in the borehole. High concentrations of $\mathrm{Fe}$ are present both in the shallow and deep parts of the borehole (Fig. 1Q). We suspected that this shallow enrichment is due to a contamination of the borehole fluids by the steel casing, and any flakes of rust knocked off during the sampling process. Goethite and X-ray amorphous iron hydroxides were observed by X-ray diffraction spectrometry (XRD) on the suspended solids recovered from the samples. Precipitation of orange Fe oxides in the untreated sample aliquots was observed for approximately one week following sampling. Iron precipitation was clearly caused by atmospheric exposure in Sample 137 504B BL-001M, as a result of difficulties during sample extraction (see above). Other samples were filtered and acidified with minimal exposure to the air. Precipitation of iron oxyhydroxides in the borehole itself is likely, particularly at shallow depths where relatively oxic bottom water is in contact with the steel casing, potentially causing oxidation and mobilization of iron. Red filaments $(<10 \mathrm{~mm}$ diameter, and $<200 \mathrm{~mm}$ long) were present on the filters from the borehole fluid samples. Scanning electron microscope (SEM) investigation of similar filaments from Leg 111 (Shipboard Scientific Party, 1988) revealed that these were probably bacterial in origin, and resembled iron oxidizing bacteria. The presence of iron oxidizing bacteria may indicate that oxidation of the casing or of dissolved $\mathrm{Fe}$ produces $\mathrm{Fe}$-oxyhydroxides in the borehole environment. The source for high $\mathrm{Fe}$ at depth is equivocal: it may originate from a basaltic source, or merely from the dissolution of rust fallen from the casing. For iron and elements with similar element vs. element trends, distribution in the borehole fluids may be controlled by dissolution (oxidation) of the casing, precipitation as iron oxyhydroxides, and/or redissolution upon sinking to the more reducing borehole fluids deeper in the hole. For example B vs. Mg (Fig. 2N) shows a mirror image of the Fe vs. Mg trend, and may be produced by co-precipitation of B with $\mathrm{Fe}$-oxyhydroxide phases in high $\mathrm{Fe}$ environments, or during sampling. 
Table 3. Raw data for Leg 137 borehole fluids.

\begin{tabular}{|c|c|c|c|c|c|c|c|c|c|c|}
\hline $\begin{array}{l}\text { Sample: } \\
\text { Depth (mbsf): }\end{array}$ & $\begin{array}{c}137504 \mathrm{~B} \\
\text { BL-001M } \\
350\end{array}$ & $\begin{array}{c}137504 \mathrm{~B} \\
\mathrm{BL}-002 \mathrm{M} \\
520\end{array}$ & $\begin{array}{c}137504 \mathrm{~B} \\
\mathrm{BB}-003 \mathrm{M} \\
800\end{array}$ & $\begin{array}{c}137504 \mathrm{~B} \\
\text { BL-004M } \\
950\end{array}$ & $\begin{array}{c}137504 \mathrm{~B} \\
\text { BB-005M } \\
1100\end{array}$ & $\begin{array}{c}137504 \mathrm{~B} \\
\text { BB-007M } \\
1400\end{array}$ & $\begin{array}{c}137504 \mathrm{~B} \\
\text { BL-008M } \\
1500\end{array}$ & $\begin{array}{c}137504 \mathrm{~B} \\
\mathrm{BB}-009 \mathrm{M} \\
1550\end{array}$ & $\begin{array}{c}\text { Surface } \\
\text { water }\end{array}$ & $\begin{array}{l}\text { Deep } \\
\text { water* }\end{array}$ \\
\hline $\mathrm{pH}$ & 6.87 & 7.2 & 7.13 & 7.27 & 6.82 & 7.08 & 5.66 & 5.84 & 8.03 & 7.62 \\
\hline Alk (mM) & 2.32 & 2.50 & 2.10 & 2.03 & 1.90 & 1.90 & 1.74 & & 2.36 & 2.50 \\
\hline Salinity $(\mathrm{g} / \mathrm{kg})$ & 34.2 & 34.8 & 34.8 & 35.2 & 34.1 & 34 & 33.4 & 33.5 & 33.5 & 34.8 \\
\hline $\mathrm{Cl}^{-}(\mathrm{mM})$ & 554 & 552.9 & 553.2 & 555 & 556.9 & 557.8 & 564.3 & 559.9 & 554 & 554 \\
\hline $\mathrm{Mg}^{2+}(\mathrm{mM})$ & 54.02 & 50.74 & 45.29 & 53.67 & 42.32 & 43.92 & 26.88 & 35.91 & 53.75 & 5341 \\
\hline $\mathrm{Ca}^{2+}(\mathrm{mM})$ & 10.7 & 13.5 & 19.8 & 10.3 & 22.8 & 21.9 & 43.0 & 31.2 & 10.3 & 10.5 \\
\hline $\mathrm{SO}_{4}^{2-}(\mathrm{mM})$ & 29.6 & 27.0 & 23.1 & 28.0 & 19.9 & 20.2 & 6.1 & 14.4 & 27.7 & 28.6 \\
\hline $\mathrm{H}_{4} \mathrm{SiO}_{4}(\mathrm{mM})$ & 0.019 & 0.395 & 0.951 & 0.027 & 1.213 & 1.066 & 1.802 & 1.728 & 0.002 & 0.165 \\
\hline $\mathrm{Na}^{+}(\mathrm{mM})$ & 481 & 473 & 462 & 473 & 449 & 455 & 409 & 433 & 473 & 475 \\
\hline $\mathrm{K}^{+}(\mathrm{mM})$ & 10.5 & 10.1 & 9.6 & 10.1 & 9.4 & 9.5 & 8.4 & 8.9 & 10.3 & 10.4 \\
\hline $\mathrm{Sr}^{2+}(\mu \mathrm{M})$ & 86.2 & 87.6 & 81.9 & 86.0 & 75.0 & 79.1 & 66.3 & 72.0 & 86.0 & \\
\hline $\mathrm{Li}^{+}(\mu \mathrm{M})$ & 37.6 & 33.5 & 34.4 & 32.0 & 39.6 & 37.7 & 53.3 & 46.9 & 29.0 & \\
\hline $\mathrm{NH}_{4}^{+}(\mu \mathrm{M})$ & 24 & 4 & 16 & 6 & 16 & 17 & 35 & 24 & 0 & \\
\hline $\mathrm{NO}_{3}^{-}(\mu \mathrm{M})$ & 23.5 & 22.5 & 6.25 & 38.8 & 8.59 & 8.07 & 1.06 & 2.75 & 8.02 & 39.1 \\
\hline $\mathrm{NO}_{2-}(\mu \mathrm{M})$ & 1.38 & 2.49 & 3.45 & 0.23 & 2.82 & 1.44 & 0.33 & 0.25 & 0.38 & \\
\hline $\mathrm{PO}_{4}^{3-}(\mu \mathrm{M})$ & .00 & .29 & .50 & .00 & .70 & .29 & .70 & .70 & .70 & \\
\hline $\mathrm{Br}^{-4}(\mu \mathrm{M})$ & 821 & 816 & 799 & 829 & 819 & 813 & 812 & 821 & 820 & \\
\hline $1(\mu M)$ & 19.8 & 18 & 50.6 & 9.2 & 21.9 & 21.8 & 37 & 27.3 & & \\
\hline $\mathrm{Fe}(\mu \mathrm{M})$ & 338 & 437 & 191 & & 202 & 180 & 686 & 237 & 0 & \\
\hline $\mathrm{Mn}(\mu \mathrm{M})$ & 50 & 35 & 59 & & 75 & 75 & 116 & 97 & 0 & \\
\hline $\mathrm{B}(\mu \mathrm{M})$ & 386 & 416 & 422 & 407 & 423 & 423 & 381 & 412 & 407 & \\
\hline$\delta^{11} \mathrm{~B}(\%)$ & & 37.9 & & 37.9 & & 38.3 & 37.4 & & 38.8 & \\
\hline$\delta^{34} S(\% o)$ & 20.1 & & & 20 & 19.7 & 19.7 & 19.5 & & 20 & \\
\hline${ }^{3} \mathrm{He} /{ }^{4} \mathrm{He}\left(\mathrm{R}_{\mathrm{a}}\right)$ & 4.84 & & 1.103 & 1.039 & 4.001 & 1.301 & & & & \\
\hline$\delta^{18} \mathrm{O}(\%)$ & 0.44 & 0.11 & 1.58 & 0.38 & 0.02 & 0.02 & -0.13 & -0.05 & & \\
\hline$\delta \mathrm{P}_{1}(\%)$ & -3.3 & -8.9 & -4.9 & -5.4 & -6.5 & -7.6 & -5.2 & -5.7 & & \\
\hline$\delta^{13} \mathrm{C}(\% \circ)$ & -1.1 & -2.1 & & -2.1 & -1.2 & -1.4 & -2.1 & -2.2 & & \\
\hline $\begin{array}{l}{ }^{87} \mathrm{Sr} /{ }^{\beta 6} \mathrm{Sr} \\
\delta^{6} \mathrm{Li}(\% \circ)\end{array}$ & 0.709212 & 0.709210 & 0.708854 & & $\begin{array}{l}0.708627 \\
-24.6\end{array}$ & 0.708750 & $\begin{array}{r}0.707575 \\
-18.0\end{array}$ & $\begin{array}{l}0.708240 \\
-22.0\end{array}$ & 0.709194 & \\
\hline $\mathrm{La}(\mu \mathrm{g} / \mathrm{kg})$ & 0.647 & 0.887 & 0.479 & & 0.604 & 0.513 & 1.005 & 0.472 & & \\
\hline $\mathrm{Ce}(\mu \mathrm{g} / \mathrm{kg})$ & 0.896 & 3.275 & 0.609 & & 0.667 & 0.593 & 0.688 & 0.652 & & \\
\hline $\operatorname{Pr}(\mu \mathrm{g} / \mathrm{kg})$ & 0.07 & 0.183 & 0.05 & & 0.077 & 0.052 & 0.068 & 0.06 & & \\
\hline $\mathrm{Nd}(\mu \mathrm{g} / \mathrm{kg})$ & 0.214 & 0.542 & 0.155 & & 0.240 & 0.17 & 0.215 & 0.189 & & \\
\hline $\mathrm{Sm}(\mu \mathrm{g} / \mathrm{kg})$ & 0.028 & 0.071 & 0.022 & & 0.023 & 0.025 & 0.052 & 0.03 & & \\
\hline $\mathrm{Eu}(\mu \mathrm{g} / \mathrm{kg})$ & 0.043 & 0.017 & 0.011 & & 0.021 & 0.019 & 0.104 & 0.029 & & \\
\hline $\mathrm{Gd}(\mu \mathrm{g} / \mathrm{kg})$ & 0.041 & 0.081 & 0.029 & & 0.035 & 0.033 & 0.07 & 0.041 & & \\
\hline $\mathrm{Tb}(\mu \mathrm{g} / \mathrm{kg})$ & 0.007 & 0.010 & 0.005 & & 0.005 & 0.005 & 0.007 & 0.006 & & \\
\hline Dy $(\mu \mathrm{g} / \mathrm{kg})$ & 0.022 & 0.025 & 0.014 & & 0.015 & 0.014 & 0.022 & 0.02 & & \\
\hline $\mathrm{Ho}(\mu \mathrm{g} / \mathrm{kg})$ & 0.003 & 0.004 & 0.002 & & 0.002 & 0.002 & 0.004 & 0.003 & & \\
\hline $\mathrm{Er}(\mu \mathrm{g} / \mathrm{kg})$ & 0.015 & 0.018 & 0.011 & & 0.010 & 0.01 & 0.014 & 0.014 & & \\
\hline $\operatorname{Tm}(\mu \mathrm{g} / \mathrm{kg})$ & 0.004 & 0.004 & 0.002 & & 0.002 & 0.002 & 0.004 & 0.003 & & \\
\hline $\mathrm{Yb}(\mu \mathrm{g} / \mathrm{kg})$ & 0.014 & 0.015 & 0.009 & & 0.008 & 0.007 & 0.016 & 0.012 & & \\
\hline $\mathrm{Lu}(\mu \mathrm{g} / \mathrm{kg})$ & 0.005 & 0.005 & 0.003 & & 0.003 & 0.003 & 0.006 & 0.004 & & \\
\hline
\end{tabular}

Note: *Mottl and Gieskes, 1990.

Scavenging of boron onto iron oxyhydroxides is likely as high boron concentrations have been observed in metalliferous sediment on the East Pacific Rise (Marchig et al., 1986).

Figure 3 shows the REE patterns for the borehole fluid samples normalized to normal mid-ocean-ridge basalt (N-MORB). All fluid samples are enriched in REEs relative to seawater. The patterns are similar to those observed in hydrothermal vent fluids (Michard, 1989) with an enrichment in light REE (LREE) relative to heavy REE (HREE) and a positive Eu anomaly. In general, Eu increases with decreasing $\mathrm{Mg}$ (Table 3 ). A very large Eu anomaly is observed in the shallowest sample (137 504B BL-001M, $350 \mathrm{mbsf}$ ), whereas the major element chemistry is very close to seawater composition. Sample 137 504B BL-002M (520 mbsf), is the only sample in which a slightly negative Eu anomaly is observed, and the LREE are enriched relative to all other samples. Perhaps the elevated REE and lack of a positive $\mathrm{Eu}$ anomaly originates from redissolution of $\mathrm{Fe}$-oxyhydroxides as they fall deeper into hotter, more reducing conditions (Sholkovitz et al., 1989). Figure 3 (inset) shows the Eu anomaly, defined as $\mathrm{Eu} / \mathrm{Eu}$, where $\mathrm{Eu}^{\prime \prime}=(\mathrm{Sm}+\mathrm{Gd}) / 2$, plotted vs. $\mathrm{Mg}$. A reasonable mixing line is observed, with the exception of Sample 137 504B BB-002M (520 mbsf). The fact that the Eu anomaly for 137 504B BB-002M falls off the mixing trend observed for all other samples suggests a different source for the Eu anomaly than for the other samples. This, combined with the observation that the REE are enriched in all samples (even those with little or no change from seawater chemistry), suggests that there is a source of REE in addition to seawater/basalt reaction. This contamination may arise from interaction of the fluids with: (1) drill string greases, (2) drilling mud, and/or (3) steel components of the casing. Enrichment of Fe in the shallowest samples argues in favor of contamination by dissolution and oxidation of the steel casing.

$\mathrm{NO}_{3}+\mathrm{NO}_{2}$ and $\mathrm{NH}_{4}$ show behavior similar to $\mathrm{B}$ and $\mathrm{Fe}$ when plotted vs. $\mathrm{Mg}$ (Fig. 20). The presence of these species is likely due to contamination of the borehole fluids with greases from the drill string, as only a small amount of pipe grease could account for the observed changes in $\mathrm{NO}_{3}+\mathrm{NO}_{2}$ in the samples (Shipboard Scientific Party, 1992a). Perhaps the inverse relationship between $\mathrm{NH}_{4}$ and $\mathrm{NO}_{3}$ $+\mathrm{NO}_{2}$ is due to higher temperatures and more reducing conditions at depth in the borehole (Table 3 ). In any case it is important to note that whereas in the past $\mathrm{NO}_{3}+\mathrm{NO}_{2}$ measurements have been used to correct for any entrainment of bottom water into the samples (Mottl and Gieskes, 1990), in this study no such corrections have been made. $\mathrm{Br}$ displays no noticeable change relative to $\mathrm{Mg}$ (Fig. $2 \mathrm{P}$ ) in the borehole within analytical resolution.

\section{Anhydrite Precipitation}

The recovery of anhydrite crusts (Shipboard Scientific Party, 1992a, fig. 21) during the initial equipment recovery operations of Leg 137 suggests that this mineral precipitated within the borehole. Sulfur isotopic studies of the anhydrite and of dissolved sulfate in the borehole fluids provide further support for this conclusion (Table 3 and Fig. 1G). The fluid sample from $350 \mathrm{mbsf}$ has a $\delta^{34} \mathrm{~S}$ equal to that of modern seawater $\left(\delta^{34} \mathrm{~S}=+20 \%\right)$. With depth the $\delta^{34} \mathrm{~S}$ decreases to a value of $+19.5 \%$ at 1500 mbsf. The sulfur isotopic composition of the anhydrite crust was $+21.4 \%$. The results are consistent with a slight positive fractionation of sulfur isotopes expected during precipitation of anhydrite (Holser and Kaplan, 1966). XRD analysis of 

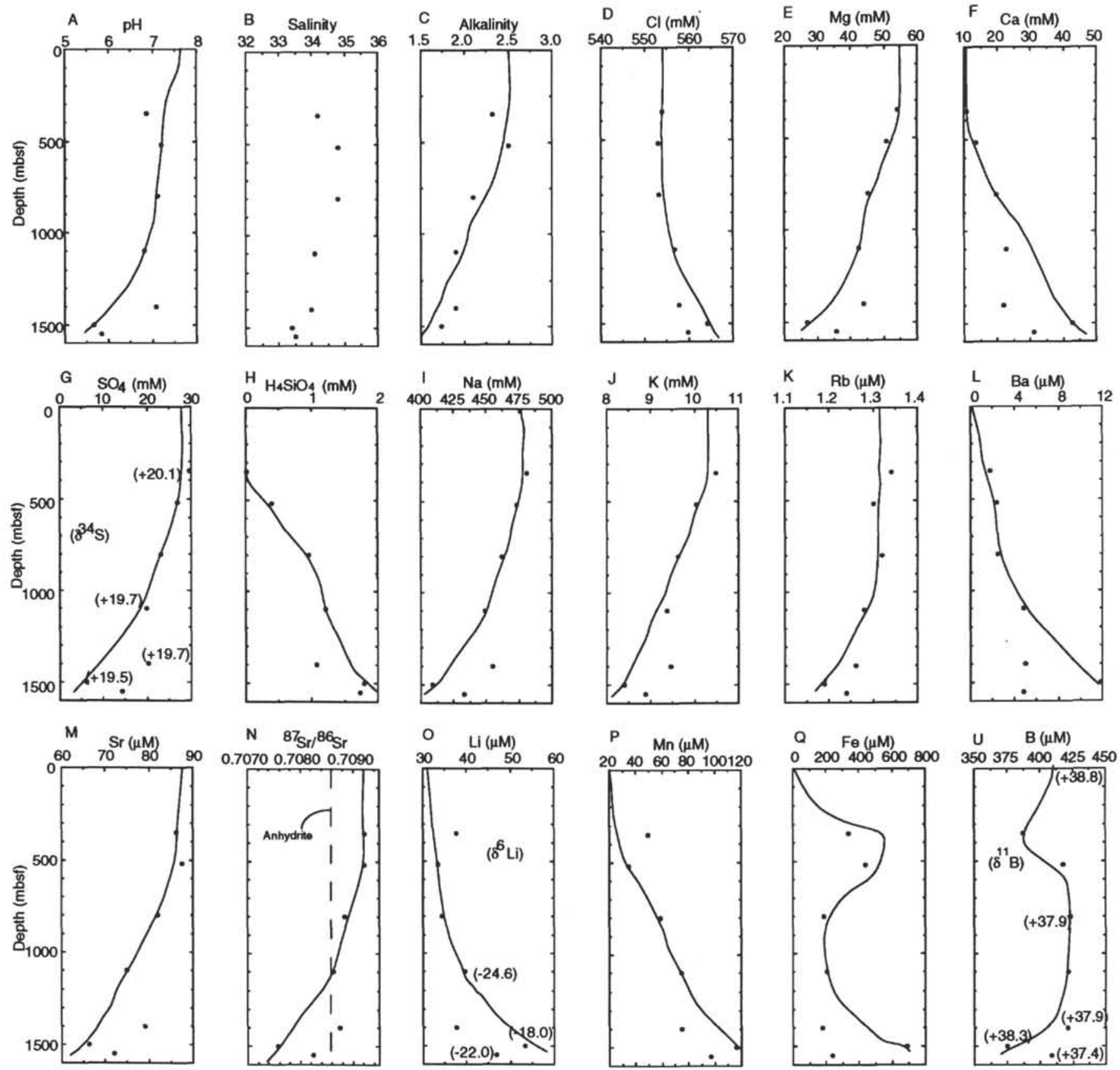

Figure 1. Component vs. depth profiles for Hole 504B borehole fluids collected during Leg 137. Values in parentheses are isotopic composition for the elements at the depth specified. Dashed line in Figure $1 \mathrm{~N}$ is the ${ }^{87} \mathrm{Sr} /{ }^{86} \mathrm{Sr}$ for the anhydrite crusts recovered from the hole before drilling.

the suspended solids also revealed the major peaks of anhydrite in samples from below 1100 mbsf (Shipboard Scientific Party, 1992a). Gypsum was observed in the "fluid" samples recovered during Leg 92 from Hole 504B (Gieskes et al., 1986). However, the extent to which this observation was caused by the large quantity of drilling mud left in the borehole, as a result of inefficient flushing at the end of Leg 83, left this conclusion somewhat ambiguous.

Further indication that anhydrite precipitation is expected from the moderate temperature borehole fluids comes from experimental investigations. Anhydrite has been observed to precipitate during heating of seawater to temperatures as low as $200^{\circ} \mathrm{C}$ (Bischoff and Seyfried, 1978) and $150^{\circ} \mathrm{C}$ during experimental reaction of seawater and basalt (Seyfried and Bischoff, 1979). The thermodynamic saturation index of anhydrite $(\Omega=$ ion activity product divided by the solubility product) has been calculated for the borehole fluids at their in situ conditions and compositions. This has been done using the database of D. Janecky (pers. comm., 1992) and the results are presented in Figure 4. The logarithm of the saturation index for anhydrite reaches a value of $\Omega=0$ (saturation) near $1100 \mathrm{mbsf}\left(\mathrm{T}=140^{\circ} \mathrm{C}\right.$ ), revealing that the borehole is at or above saturation below this depth. This is coincidentally the same depth at which anhydrite was first observed in the suspended solids from the borehole fluid samples. The slight degree of supersaturation in the deepest sample may be the result of dilution of fluids during ascent of the sample (entrainment evident in downhole profiles; see Fig. 1), resulting in an apparent supersaturation (Mazor, 1992).

Six replicate analyses of $\mathrm{Sr}$ isotopes on different pieces of the anhydrite crusts, including analysis across a single crust, yielded a surprisingly uniform result with a mean isotope ratio of ${ }^{87} \mathrm{Sr} /{ }^{86} \mathrm{Sr}=$ 0.708600 (std. dev. $=0.000021$ ). This value is considerably more radiogenic than the water sample from $1500 \mathrm{mbsf}$, which had ${ }^{87} \mathrm{Sr} /{ }^{86} \mathrm{Sr}$ $=0.707575$, and matches closely with the ${ }^{87} \mathrm{Sr} /{ }^{86} \mathrm{Sr}$ of the sample from 

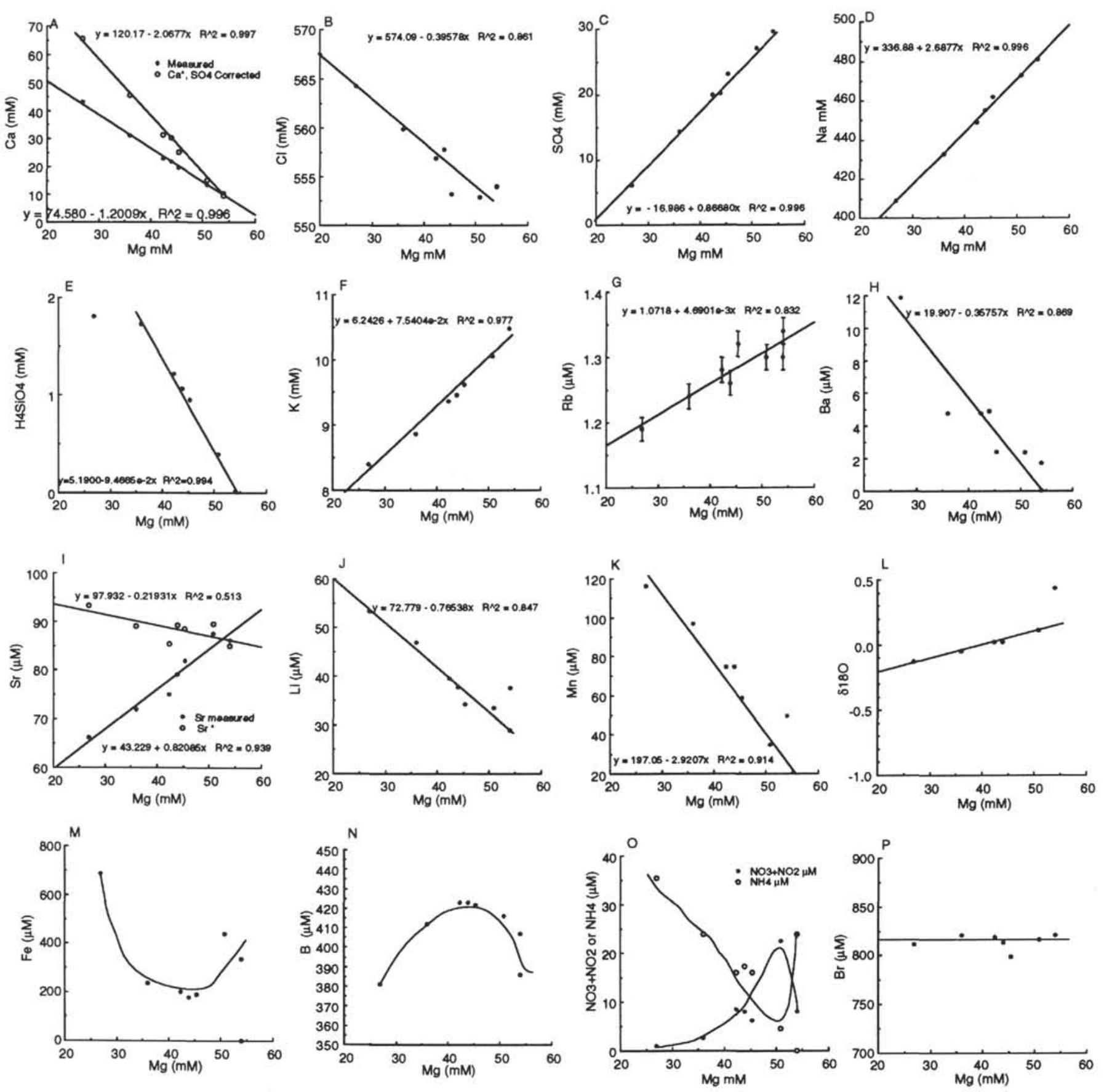

Figure 2. Component vs. Mg for Hole 504B borehole fluid collected during Leg 137. Values for Ca and $\mathrm{Sr}$ are also presented as corrected for anhydrite precipitation ( $\mathrm{Ca}^{*}$ and $\mathrm{Sr}^{*}$ ), based on the deficit of $\mathrm{SO}_{4}$ from the seawater value of $28 \mathrm{mM}$ (see text).

1100 mbsf with ${ }^{87} \mathrm{Sr} /{ }^{86} \mathrm{Sr}=0.708627$ (Fig. 1N). This suggests that the recovered anhydrite may have formed near $1100 \mathrm{mbsf}$, coincidentally the same depth at which anhydrite saturation is first approached in the borehole fluids (Fig. 4). Alternately, the recovered anhydrite may have formed deeper in the borehole at a time when the fluids were more radiogenic than at present, perhaps as the fluid was rapidly heated to the formation temperatures.

\section{Evidence For Seawater/Basalt Interaction}

While anhydrite precipitation appears to occur directly from the water in the borehole itself, most of the large chemical changes cannot be explained without evoking seawater-basalt exchange. In fact, the quantity of $\mathrm{Ca}$ released into the borehole fluids due to reaction with basalt is greater than measured because of the removal of $\mathrm{Ca}$ into anhydrite. Corrected $\mathrm{Ca}$ is presented as $\mathrm{Ca}^{\circ}$ on the mixing diagram Figure $2 \mathrm{~A}$, where $\mathrm{Ca}^{*}$ is the $\mathrm{Ca}$ concentration in absence of anhydrite precipitation as calculated form the decrease in $\mathrm{SO}_{4}$ from seawater concentration. A similar correction can be made for Sr. While the data show a decrease in $\mathrm{Sr}$ with depth in the borehole, analysis of the anhydrite crusts revealed a Sr/Ca molar ratio of $0.0012(2 \sigma=$ $0.00005, n=4)$. Accounting for this export of $\mathrm{Sr}$ from the fluids based on the decrease in $\mathrm{SO}_{4}$ concentration indicates a net input of $\mathrm{Sr}$ to the borehole fluids through reaction with basalt $\left(\mathrm{Sr}^{*}\right.$ in Fig. 2I).

The $\mathrm{Sr}$ isotopic evidence is one of the most convincing arguments for basaltic input to the borehole waters. $\mathrm{Sr}$ in the fluids is a mixture 
of seawater-derived $\mathrm{Sr}\left({ }^{87} \mathrm{Sr} /{ }^{86} \mathrm{Sr}=0.70918\right)$ and basaltic $\mathrm{Sr}\left({ }^{87} \mathrm{Sr} /{ }^{86} \mathrm{Sr}\right.$ $=0.70272$; Shimizu et al., 1989). Similar evidence is reflected in the ${ }^{3} \mathrm{He} /{ }^{4} \mathrm{He}$ results (Table 3 ). While many of the samples have $\mathrm{R}_{\mathrm{a}}\left(\mathrm{R}_{\mathrm{a}}=\right.$ ${ }^{3} \mathrm{He} /{ }^{4} \mathrm{He}$ measured divided by ${ }^{3} \mathrm{He} /{ }^{4} \mathrm{He}$ in air) near 1 , two samples have ratios near 4 . The samples with ratios near 1 were probably contaminated by atmospheric gas during either sampling or storage. Ratios as high as 4 cannot be explained by contamination, and reflect the greater abundance of mantle-derived ${ }^{3} \mathrm{He}$ trapped in fresh basalts. Hence both $\mathrm{Sr}$ and $\mathrm{He}$ isotopes support seawater/basalt interaction, but the location of reaction, whether in the formation or in the borehole, is unresolved.

Scanning electron microscopic (SEM) analyses of pieces of basaltic rubble from the bottom of Hole 504B (Fig. 5A), collected prior to any drilling operations during Leg 137 , revealed the ubiquitous presence of $100-200 \mu \mathrm{m}$ coatings of Mg-rich smectite/chlorite clays. The presence of these reaction products on the exterior surfaces of many of the rubble fragments strongly suggests that the clay coatings formed after the rubble fell to the bottom of the hole. Mg-rich smectite was observed intergrown in the anhydrite crusts as well (Fig. 5B). Results of electron microprobe analyses on the clay coatings and from within the anhydrite are presented in Figure 6 in an attempt to distinguish these clays from those occurring within the cored basalts. The clays coating the rubble have compositions quite similar to mixed-layer clays collected in the cored samples, but the clays interbedded in the anhydrite matrix are quite distinct, having very low Fe and $\mathrm{Al}$ contents, near the talc-chlorite endmember. Although the chemistry of the clay coatings does not unequivocally support in-situ formation, the fact that the surfaces of many of the pieces were covered with these skins of reaction products supports the hypothesis that reaction occurred at the hole bottom. The $\mathrm{Al}$-poor nature of the smectite within the anhydrite crusts is consistent with direct precipitation from solution.

$\mathrm{Mg}$-rich clays are the likely sink for $\mathrm{Mg}$ from the borehole fluids. Alteration of basalt by seawater often involves the formation of $\mathrm{Mg}$-rich clays in experimental simulations at temperatures as low as $70^{\circ} \mathrm{C}$ with the net result being an approximately $1: 1$ exchange of $\mathrm{Mg}$ for Ca (e.g., Seyfried and Bischoff, 1979). However, in the borehole fluids there is almost a 2:1 Ca:Mg exchange ( $\mathrm{Ca}^{*}$; see above, Fig. 2A). $\mathrm{Na}$ is also removed from the borehole fluids, but a sink for $\mathrm{Na}$ is less readily identified. Zones of albitized plagioclase were observed during elemental mapping using electron dispersive spectrometry of some of the pieces of rubble (Magenheim et al., 1991). However, albite is an observed alteration product in the cored formation itself, and thus this evidence is equivocal in respect to the sink for $\mathrm{Na}$ within the borehole. Other potential sinks for $\mathrm{Na}$ are the formation of sodic zeolites or clays.

\section{Isotopic Investigations: Reaction Zone Constraints}

One of the strongest arguments against reaction with the borehole walls as the source for the reacted fluids observed in Hole 504B was that the borehole itself is a system physically dominated by the quantity of fluid (Mottl and Gieskes, 1990). Water in a borehole of radius $15 \mathrm{~cm}$ reacting with $0.5 \mathrm{~mm}$ of basalt lining the hole yields a water/rock mass ratio $(\mathrm{w} / \mathrm{r})$ of near 60 . This value is a minimum, as the borehole contains a larger volume of water relative to surface area due to the uneven diameter of the walls as a consequence of cave-ins. At w/r ratios this high, a small volume of altered rock is required to gain up to $6 \% \mathrm{MgO}, 9 \% \mathrm{Na}_{2} \mathrm{O}$, and lose $20 \% \mathrm{CaO}$ to account for the changes observed in the fluid chemistry based on results from Leg 111 (Mottl and Gieskes, 1990). Thus, it seems unlikely that the degree of reactivity observed could be explained merely by reaction with the basalts on the borehole walls.

An alternate reaction zone is in the rubble at the bottom of the hole. This reaction zone would, of course, have a much lower physical w/r than the open borehole, thus eliminating the above inconsistency. As already discussed, analysis of the alteration rinds on these rock pieces does not conclusively eliminate the possibility that the secondary

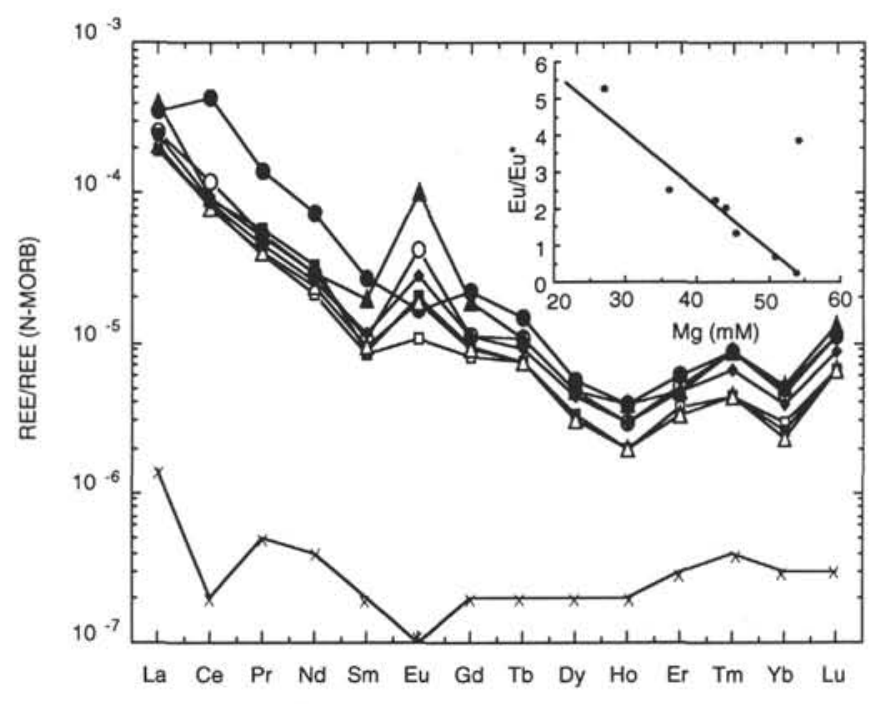

Figure 3. N-MORB (Sun and McDonough, 1989) normalized rare-earth element (REE) distributions for Leg 137 Hole 504B borehole fluids, and seawater. Europium anomaly (Eu/Eu*) vs. $\mathrm{Mg}$ (inset), where $\mathrm{Eu}=(\mathrm{Sm}+\mathrm{Gd}) / 2$. Open circle $=137504 \mathrm{~B}$ BL-001M; solid circle $=137504 \mathrm{~B}$ BL-002M; open box $=$ 137 504B BB-003M; solid box $=137504 \mathrm{~B}$ BB-005M; open triangle $=137$ $504 \mathrm{~B}$ BB-007M; solid triangle $=137504 \mathrm{~B}$ BL-008M; diamond $=137504 \mathrm{~B}$ BB-009M; x's = seawater (Holland, 1978).

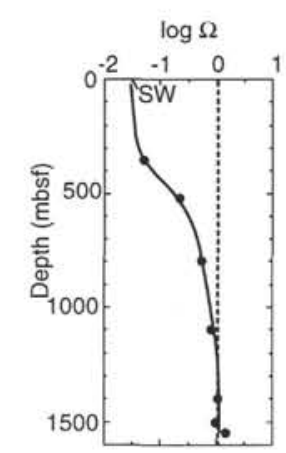

Figure 4. Anhydrite saturation state in Hole 504B. Calculation of anhydrite saturation $\left(\Omega=\right.$ ion activity product $\left./ \mathrm{K}_{\mathrm{sp}}\right)$ is based on the in-situ temperatures and measured composition of the borehole fluids. Calculations made using database of D. Janecky (pers. comm., 1992).

minerals formed in the formation prior to falling to the hole bottom (Fig. 6). Isotopic investigations of $\mathrm{Sr}, \mathrm{O}, \mathrm{H}, \mathrm{Li}$, and $\mathrm{B}$ were undertaken to evaluate the chemically derived water/rock mass ratios $(\mathrm{w} / \mathrm{r})$ in the reaction zone and the degree of reactivity of basalts at these intermediate temperatures.

To evaluate the systematics in the reaction zone it is necessary to use an extrapolated "endmember" composition of the fluids. This is necessary as the recovered solutions are clearly mixtures of the endmember and seawater, and thus, the reacting fluid must lie beyond the lowest value of $\mathrm{Mg}$ measured. Extrapolations for each isotope were made to zero $\mathrm{Mg}$, defining a single reacted fluid endmember for the borehole system. This extrapolation is justified because for moderate to low w/r experimental systems at temperatures greater than $150^{\circ} \mathrm{C}$ $\mathrm{Mg}$ is completely removed in periods of less than or equal to one year (Mottl, 1983; Seyfried, 1987; Seyfried and Bischoff, 1979). Such extrapolations are commonly used during the study of high temperature $\left(\geq 300^{\circ} \mathrm{C}\right)$ hydrothermal fluids, to remove the effects of entrainment of seawater during sampling (e.g., Von Damm et al., 1985). While it is possible that there is not a fluid with $\mathrm{Mg}=0 \mathrm{mM}$ in the borehole, reaction to this extent is likely in the fine- to coarse-grained 
A

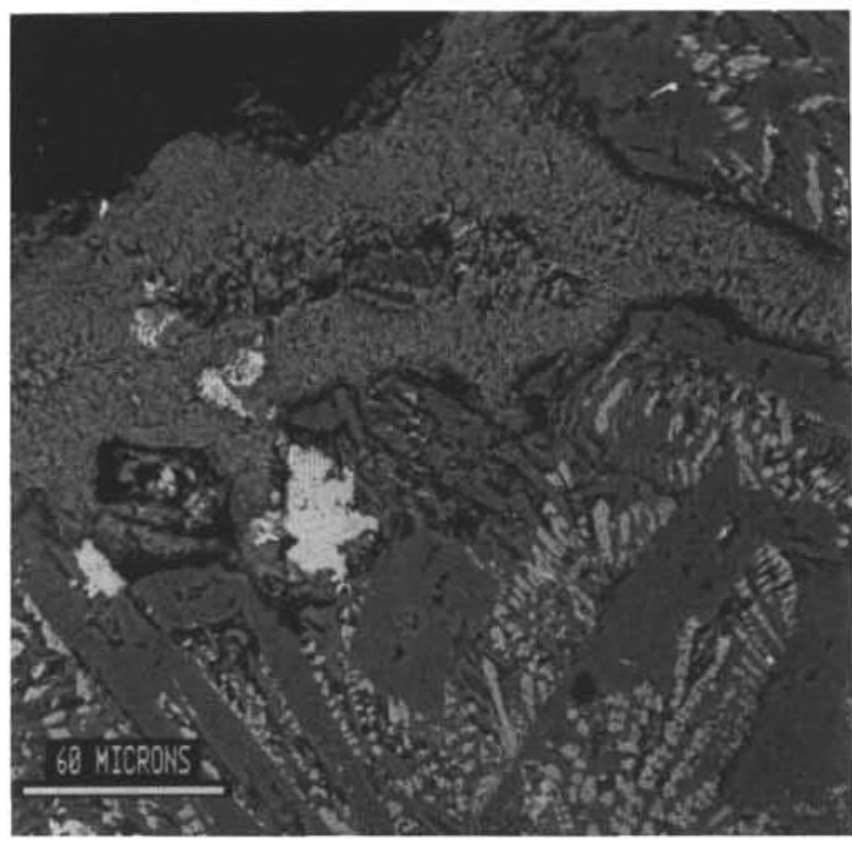

B

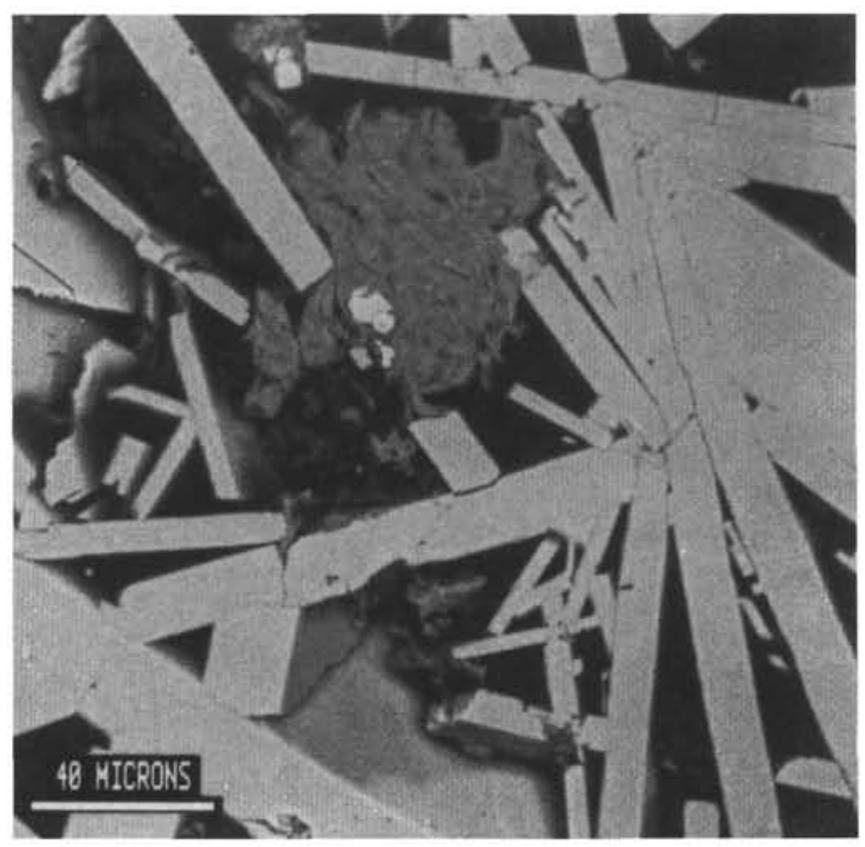

Figure 5. SEM image of (A) basaltic rubble piece coated with reaction products, and (B) anhydrite crust with interbedded clay.

basaltic rubble at the bottom of the borehole. In addition, extrapolation to zero $\mathrm{Mg}$ provides a uniform reference to previous sample suites from Hole 504B. The subject of borehole fluid endmembers will be discussed further in a later section.

For $\delta \mathrm{D}$ and $\delta^{13} \mathrm{C}$ the measured values are lower than of fresh seawater ( $\sim \%$ for both) and show no definable trends when compared with Mg. This indicates the possibility of contamination of the samples for these isotopes. Evaporation can be ruled out as the sam- ples were stored in sealed glass vials, and evaporation would increase the values of both $\delta \mathrm{D}$ and $\delta^{13} \mathrm{C}$. Boron concentration shows a minimum in both the shallowest and deepest samples (Fig. $2 \mathrm{~N}$ ). As discussed earlier, B appears to be affected by the cycling of $\mathrm{Fe}$ in the borehole, and its concentration and isotopic composition are likely influenced by oxidation of the casing in the upper hole and subsequent removal into iron oxyhydroxide phases. The endmembers for $\delta^{13} \mathrm{C}, \delta \mathrm{D}$, and $\delta^{\prime \prime} \mathrm{B}$ cannot be defined due to the non-conservative mixing observed. $\mathrm{Li}, \mathrm{Sr}$, and oxygen isotopes, however, do reflect exchange between basalt and the borehole fluids, and these results will be used to elucidate information about the reaction zone.

Oxygen isotopes show a mixing trend with $\mathrm{Mg}$ (Fig. $2 \mathrm{~L}$ ), revealing an endmember of $\delta^{18} \mathrm{O}=-0.41 \%$ at zero $\mathrm{Mg}$, and intersecting close to $0.1 \%$ for seawater at $\mathrm{Mg}=54 \mathrm{mM}$. Equilibrium models for isotopic exchange (Cole et al., 1987) reveal that water in equilibrium with fresh basalt $\left(\delta^{18} \mathrm{O}=5.7 \%\right.$ ) at $\mathrm{T}=162^{\circ} \mathrm{C}$ should have a $\delta^{18} \mathrm{O}=-3.2 \%$. While this value is significantly lower than the endmember value from Leg 137 , it is important to note that the borehole system is probably far from equilibrium conditions with only 4.5 years of reaction. Cole et al. (1987) calculate that it would take on the order of 104 years to reach $90 \%$ of equilibrium between basalt and seawater at $200^{\circ} \mathrm{C}$.

\section{Water/Rock Mass Ratios}

To calculate the $w / r$ for the conditions of alteration based on trace element isotopic systematics (such as Sr isotopes) it is desirable first to make a decision on a reaction path (e.g., Elderfield and Greaves, 1981; Berndt et al., 1988). There are two extreme paths for reaction: precipitation followed by reaction and vice-versa. Calculation of $w / r$ from these two paths differs in that the concentration of $\mathrm{Sr}$ prior to dissolution of the basalt is different from that of the initial fluid, whereas precipitation does not alter the isotopic ratio of the fluid. A more rigorous approach to these calculations would be to make the calculation of $w / r$ by using infinitely small dissolution and precipitation steps. The incremental change in concentration of a single isotope in solution $(d X)$ can be described as a function of its concentration in fresh rock $\left(X_{r}\right)$, the alteration products $\left(X_{\text {att }}\right)$, and the incremental amount of altered rock $(d r)$ for a fixed mass of solution $(w)$ :

$$
d X / d r=\frac{X_{r}-X_{a l t}}{w}
$$

Here $X_{\text {alt }}$ is a function of the concentration of $X$ in solution, and $w$ is a mass of fluid. Implied in this expression is conservation of mass between fresh rock and alteration products. A distribution coefficient $K$ (where $X_{a l t}=K \cdot X$ ) can then be introduced into Equation 1 yielding:

$$
d X / d r=\frac{X_{r}-K X}{w}
$$

The distribution coefficient, $K$, is specific for each path specified and does not imply equilibrium reversible conditions. Equation 2 can be applied to another isotope of the same element $(Y)$, realizing that the distribution coefficient may require a fractionation correction $\left(K_{y=} \alpha K\right)$ :

$$
d Y / d r=\frac{Y_{r}-\alpha K Y}{w}
$$

Integration of Equations 2 and 3 yields two independent expressions for $r / w$ :

and

$$
r / w=K^{-1} \times \ln \left[\frac{X_{r}-K X}{X_{r}-K X_{0}}\right]
$$

$$
r / w=(\alpha K)^{-1} \times \ln \left[\frac{Y_{r}-\alpha K Y}{Y_{r}-\alpha K Y_{0}}\right]
$$

Thus, it is possible to obtain information on the distribution of an element between fluid and alteration product $(K)$ and on the water/ 


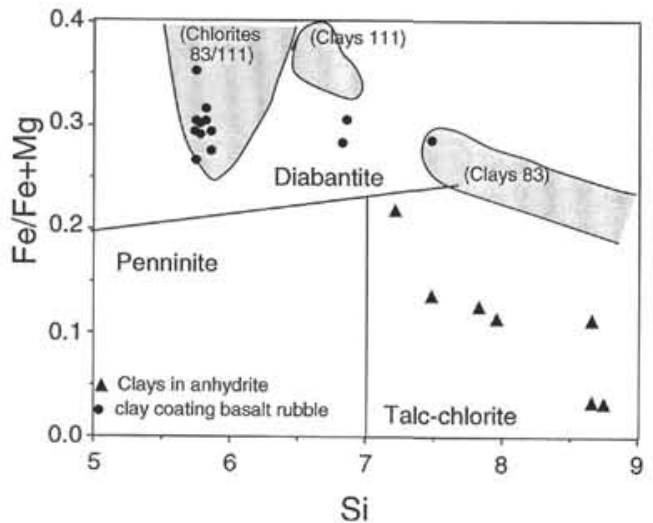

Figure 6. Chlorite/smectite compositional diagram after Hey (1954). Formulas calculated on a basis of 26 oxygens. Field from clays recovered in the cored formation are included for reference (Alt et al., 1989).

rock mass ratio $(\mathrm{w} / \mathrm{r})$ from the concentration and isotopic composition of an element in the initial and final fluids and in the fresh rock. The $w / r$ ratio calculated in this manner is an indication of the degree of reactivity of the rock for the specific element from which it is calculated. In this respect, the calculated $w / r$ ratio represents the quantity of rock from which the element has been completely mobilized into a constant amount of water. Hence, an element that is incompletely mobilized will result in calculation of a larger $w / r$ than for an alternate element that is more mobile. Calculation of $w / r$ due to elemental/isotopic exchange will always yield a higher value than the $\mathrm{w} / \mathrm{r}$ calculated based on the physical mass of water and rock in the system (see above) in the absence of $100 \%$ mobilization of the element in question.

Calculations have been made for $w / r$ and the distribution coefficient, $K$, for the exchange of $\mathrm{Sr}$ and $\mathrm{Li}$ based on abundance and isotopic measurements. To make these calculations it is necessary to use the extrapolated endmember compositions for the Leg 137 borehole fluids as the final fluid concentration, and seawater as the starting fluid. Data for "unaltered" Hole 504B basalts were taken from several sources (Table 4).

Strontium concentration and isotopic composition were discussed briefly in the previous section on anhydrite precipitation. Although there is net $\mathrm{Sr}$ removal from the borehole waters (Fig. 1M), there is clearly an input of basaltic $\mathrm{Sr}$ (fresh Hole $504 \mathrm{~B}$ basalt ${ }^{87} \mathrm{Sr} /{ }^{86} \mathrm{Sr}=$ 0.70272; Shimizu et al., 1989), as the isotopic ratio of Sr in the borehole fluids is much less radiogenic than that of seawater (seawater ${ }^{87} \mathrm{Sr} /{ }^{86} \mathrm{Sr}$ $=0.70918)$. The endmember contains approximately $28 \% \mathrm{Sr}$ derived from basalt. Most of the decrease in $\mathrm{Sr}$ concentration is due to incorporation into anhydrite (see Fig. 2I). Thus, extrapolation of the measured values beyond $\mathrm{SO}_{4}=0(\mathrm{Mg}=6 \mathrm{mM})$ to $\mathrm{Mg}=0$ is invalid, as no more anhydrite (and hence $\mathrm{Sr}$ ) can be removed beyond this point. Because we are predominantly interested in the endmember for reaction in absence of precipitation of anhydrite (seawater/basalt reaction alone), we will use the $\mathrm{SO}_{4}$ corrected $\mathrm{Sr}^{*}$ endmember $(97 \mu \mathrm{M}, \mathrm{Fig} .2 \mathrm{G})$. For a heavy element, like $\mathrm{Sr}$, mass fractionation is relatively unimportant and $\alpha$ is assumed to be equal to 1 . Calculation of the water/rock ratio yields $\mathrm{w} / \mathrm{r}=23.5$ and $K=4.6$ (Table 4 ). The $\mathrm{w} / \mathrm{r}$ ratio is significantly less than that calculated for the open borehole based on the physical constraints ( $w / r>60$; see discussion above). From this value of $K$ we can calculate the concentration of $\mathrm{Sr}$ in the secondary minerals (in the absence of anhydrite) to be equal to $42 \mathrm{ppm}$. Calculation of $K$, based on the fluid composition at $\mathrm{SO}_{4}=0$, using the uncorrected (measured) $\mathrm{Sr}$ concentrations, yields a value of $K=32.8$, for all alteration products including anhydrite, and a concentration of $115 \mathrm{ppm} \mathrm{Sr}$ in the alteration products (Table 4). From this information and the knowledge that the anhydrite has a concentration of $774 \mathrm{ppm} \mathrm{Sr}$ (see above), it is possible to calculate that anhydrite can be a maximum of $8.5 \%$ of the total mass of reaction products.
Table 4. Comparison of water/rock ratio $(w / r)$ calculated based on borehole fluid endmembers, and calculations of $w / r$ based on $\mathrm{Sr}$ and $\mathrm{Li}$ abundance and isotopic composition.

\begin{tabular}{|c|c|c|c|c|}
\hline & $\begin{array}{c}\mathrm{Sr} \\
(\mu \mathrm{M})\end{array}$ & ${ }^{87} \mathrm{Sr} /{ }^{86} \mathrm{Sr}$ & $\begin{array}{c}\mathrm{Li} \\
(\mu \mathrm{M})\end{array}$ & $\begin{array}{c}{ }^{6} \mathrm{Li} /{ }^{7} \mathrm{Li} \\
(\% \circ)\end{array}$ \\
\hline $\begin{array}{l}\text { Seawater } \\
504 \mathrm{~B}-008 \\
\text { Endmember }(\mathrm{Mg}=0) \\
\qquad\left[\mathrm{SO}_{4}=0\right] \\
\text { Fresh basalt }(504 \mathrm{~B}) \\
\text { Fractionation factor }(\alpha)\end{array}$ & $\begin{array}{c}87 \\
66.3 \\
97^{\mathrm{i}} \\
|60| \\
60 \mathrm{ppm}^{\mathrm{b}}\end{array}$ & $\begin{array}{c}0.70918 \\
0.70756 \\
0.70743 \\
{[0.70754]} \\
0.70272^{\mathrm{c}} \\
1.0000\end{array}$ & $\begin{array}{c}29 \\
53 \\
78 \\
2 \mathrm{ppm}^{\mathrm{d}} \\
1.008-1.009\end{array}$ & $\begin{array}{l}-32.3 \\
-18.0 \\
-13.7 \\
-5.0^{\mathrm{e}}\end{array}$ \\
\hline & & $\mathrm{Sr}$ & & $\mathrm{Li}$ \\
\hline $\begin{array}{l}w / r \\
K\end{array}$ & & $\begin{array}{c}23.5[32.8 \mid \\
4.9 \mid 21.8\}\end{array}$ & & $\begin{array}{l}2.2-3.1 \\
3.0-2.4\end{array}$ \\
\hline
\end{tabular}

Notes: Calculations are described in text. $\mathrm{Li}, \mathrm{w} / \mathrm{r}$, and $\mathrm{K}$ are given for a range of the isotopic fractionation of $\alpha=1.008-1.009$, intermediate between fraction observed for axial high temperature reaction and seafloor weathering. Disagreement between different isotopic systems reflects differing mobilities. All calculations are supportive of a low w/r $(<50)$ suggesting a rock-dominated system.

${ }^{\mathrm{a}} \mathrm{Sr}$ t corrected for anhydrite is used in this calculation; see text. Values for $\mathrm{Sr}$ and $\mathrm{Sr}$ isotopes at $\mathrm{SO}_{4}=0$ are not corrected for anhydrite precipitation; these values, and w/r and $\mathrm{K}$ calculated from them, are presented in brackets for comparison; see text.

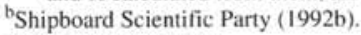

'Shimizu et al. (1989).

${ }^{\mathrm{d}}$ Mengel and Hoefs (1990).

${ }^{\mathrm{e}}$ Chan et al. (1992).

The systematics of $\mathrm{Li}$ exchange between seawater and the ocean crust is a current topic of great interest (e.g., Chan et al., 1992; Chan and Edmond, 1988). $\mathrm{Li}$ is considered to be a mobile element during reaction of seawater with basalt at temperatures greater than $70^{\circ} \mathrm{C}$ (Seyfried et al., 1984); it is leached from basalt altered at moderate to high temperature. Evidence from dredged and drilled basalts from shallow in the crust suggests that $\mathrm{Li}$ is taken up from seawater into secondary alteration products under low temperature $\left(0^{\circ}-50^{\circ} \mathrm{C}\right)$ seafloor weathering conditions (Berndt and Seyfried, 1986; Ryan and Langmuir, 1987). Li concentrations in the borehole fluids show an excellent correlation with $\mathrm{Mg}$ (Fig 2I). Hence, $\mathrm{Li}$ is interpreted to be supplied by reaction with basalt, and mixed conservatively in the borehole. Information on the temperature dependence of the fractionation of $\mathrm{Li}$ isotopes during basalt-seawater interaction is sparse. A fractionation factor of $\alpha=1.004$ for $350^{\circ} \mathrm{C}$ has been inferred from studies of hydrothermal vent fluids (Chan and Edmond, 1988). The fraction factor for basalt weathered by fresh seawater at the seafloor $\left(\mathrm{T}=2^{\circ} \mathrm{C}\right.$ ) is estimated to be near $\alpha=1.019$ (Chan et al., 1992). The $\mathrm{w} / \mathrm{r}$ ratio was calculated from the borehole fluid endmember $(\mathrm{T}=$ $162^{\circ} \mathrm{C}$ ) using fractionation factors of $\alpha=1.008$ and 1.009 , intermediate between these two extremes (Table 4 ). The distribution coefficient is calculated to be $K=2.4-3.0$, suggesting a Li concentration of $1.3-1.6 \mathrm{ppm}$ in the alteration products formed. This value of the distribution coefficient is similar in direction and magnitude to the distribution constant between seawater and secondary smectite at $200^{\circ} \mathrm{C}(K=2.3)$ derived experimentally by Berger et al. (1988). Water/rock ratios calculated based on the Li systematics yield values of 3.1 and 2.4 for $\alpha=1.008$ and 1.009 , respectively. This low value of $\mathrm{w} / \mathrm{r}$ is clearly not possible in the open borehole, but could be attained in the rubble at the hole bottom or within the formation itself.

The w/r calculated using $\mathrm{Li}$ systematics is significantly lower than that calculated based on $\mathrm{Sr}$, and the discrepancy is most likely related to the greater mobility of $\mathrm{Li}$ compared to $\mathrm{Sr}$. Similar discrepancies arise in experimental investigations and analysis of hydrothermal fluids collected at mid-ocean ridges (e.g.,Von Damm et al., 1985; Berndt et al., 1988). It is important to note that $w / r$ calculated from chemical and isotopic compositions will depend on the mobility of the individual element(s) on which the calculations are based. Berndt et al. (1988) suggest that the degree of reactivity of $\mathrm{Sr}$ (and therefore $\mathrm{Ca}$ ) bearing phases can be estimated by comparing the $\mathrm{w} / \mathrm{r}$ calculated by $\mathrm{B}$ or $\mathrm{Li}$ systems to that of $\mathrm{Sr}$. For the borehole environment, B 
appears to be influenced by processes other than simple mixing of a basalt reacted component with seawater; therefore, we use comparison between calculations based on $\mathrm{Li}$ and $\mathrm{Sr}$. The degree of reactivity of $\mathrm{Sr}$ (and therefore $\mathrm{Ca}$ bearing phases), relative to the mobile element $\mathrm{Li}$, can be expressed as the $w / \mathrm{r}(\mathrm{Li})$ divided by the $\mathrm{w} / \mathrm{r}(\mathrm{Sr})$ (Berndt et al, 1988). For the case of the Hole 504B endmember, this value is 0.113 or $11.3 \%$, using the mean of the two values for $w / r(\mathrm{Li})$. For $1 \mathrm{~kg}$ of water, $42.6 \mathrm{~g}$ of basalt could be altered using the mean w/r $=2.65$ calculated from the $\mathrm{Li}$ systematics. If all the altered material were plagioclase of composition $\mathrm{An}_{75}$, the concentration of $\mathrm{Ca}$ in the fluid would increase by 106 to $116 \mathrm{mM}$, close to the observed $\mathrm{Ca}^{*}$ for the borehole fluid endmember at $\mathrm{Mg}=0$ (Table 5). Given the composition of the endmember borehole fluid and a minimum $\mathrm{w} / \mathrm{r}$ of 2.65 (Li calculation), the $1 \mathrm{~kg}$ of fluid would lose 144 moles of Na capable of forming $37.7 \mathrm{~g}$ albite, and 54 mmoles of $\mathrm{Mg}$ capable of forming $8.0 \mathrm{~g}$ of saponite, for a total of $45.7 \mathrm{~g}$ of alteration products in agreement with the assumption of conservation of mass between alteration products and initial basalt used in the $w / r$ calculations (Eq. 1). The above calculation ignores the precipitation of anhydrite. However, if 28 mmoles of seawater $\mathrm{SO}_{4}$ are precipitated as $3.8 \mathrm{~g}$ of anhydrite, anhydrite is $8.3 \%$ by weight of the alteration products. This is very close to the calculations based on the $\mathrm{Sr}$ systematics (see above), which revealed that anhydrite is a maximum of $8.5 \%$ of the total mass of alteration products. The excellent agreement of the calculations originating from (1) the degree of reactivity, from $\mathrm{Li}$ and $\mathrm{Sr}$ isotope systematics, and (2) the changes in major element borehole fluid composition show that the comparison of multiple elemental isotope systematics for geothermal fluids can reveal important physical constraints on the reaction zone. Thus, for the case of Hole 504B borehole fluids, the $w / r$ ratio in the reaction zone must be low to support the observed chemical and isotopic changes.

\section{Formation Water Or In-situ Reaction?}

A low water/rock ratio in the reacted fluid endmember seems to eliminate the possibility of reaction within the open borehole between the borehole fluids and the exposed walls of the hole. However, the low value of $w / r$ does not distinguish between the possibility of a true formation component or reaction in the rubble pile at the borehole bottom. If the calculations of Mottl and Gieskes (1990) are correct, considerable exchange of borehole fluids with fluids from the surrounding formation should occur by molecular diffusion. These calculations are based on analysis of tritium, a definitive tracer for surface seawater, placed in the borehole during cleaning operations at the end of each drill leg. Mottl and Gieskes (1990) suggested that up to $30 \%$ of the borehole fluid should have been replaced by formation fluid in the interim between Legs 92 and 111 by molecular diffusion. However, the porosities used to calculate the diffusive exchange are based on uncorrected logging data (Mottl and Gieskes, 1990). These porosity data have since been corrected downward to values of $1 \%-2 \%$, because of the effect of alteration products on the electrical resistivity measurements (Pezard, 1990). Thus, exchange between the open borehole and formation will be small. We estimate, based on the corrected porosities, that less than $1 \%$ of the borehole fluid will be replaced in the 1233 days due to molecular diffusive exchange.

Correction of the porosities used in the calculations of Mottl and Gieskes (1990) argues against the possibility of significant exchange through the borehole walls, but advective exchange of formation fluid through a fracture or crack cannot be ruled out. It would be expected that the composition of this reacted fluid would be the same for each visit to Hole 504B if the source of reacted fluid is through a fracture rather than reaction at the borehole bottom. On the other hand, the increasing temperature at the hole bottom as Hole 504B has been drilled deeper should cause regular variation in the reacted fluid endmember if the reaction zone is at the bottom of the borehole. Reaction at the hole bottom is supported by the fact that on each leg the most reacted fluid (lowest $\mathrm{Mg}$ ) is nearest the bottom (e.g., Shipboard Scien- tific Party, 1992a). Mottl and Gieskes (1990) plotted element vs. Mg diagrams that included data for all legs, and extrapolated the combined data to a single endmember at zero $\mathrm{Mg}$. This multi-leg extrapolation was justified in that the $\mathrm{Ca}$ vs. $\mathrm{Mg}$ plot showed exceptional agreement for all legs. Substantial scatter from Leg 92, when a large amount of drilling mud was recovered in the borehole fluids, further obscured inter-leg differences for other elements. The measured $\mathrm{Ca}$ values are controlled by the saturation of the fluid with respect to anhydrite, and Magenheim et al. (1992) argue that significant and regular changes in the borehole fluid endmember did occur as the hole was drilled deeper.

Figure 7 shows the element vs. Mg mixing diagrams for each leg as a comparison. In the $\mathrm{Ca}$ vs. $\mathrm{Mg}$ plot it appears that all legs extrapolate to a single $\mathrm{Ca}$ concentration at $\mathrm{Mg}=0$ (Fig. 7A). However, when accounting for the precipitation of anhydrite, $\mathrm{Ca}^{*}$ increases monotonically between Leg 69 and 137 relative to $\mathrm{Mg}$ (Fig. 7B). This trend coincides with deepening of the hole and hence the increased bottomhole temperature. More $\mathrm{Ca}$ was liberated as the maximum borehole temperature increased from $80^{\circ} \mathrm{C}$ on Leg 70 to $162^{\circ} \mathrm{C}$ on Leg 137 (Table 1). This observation is of course supported by an increase in the $\mathrm{SO}_{4}$ removed (relative to $\mathrm{Mg}$ ) over the same interval (Fig. 7C). In fact no $\mathrm{SO}_{4}$ removal was observed on Leg 70, in agreement with the experimental observations that anhydrite precipitation from seawater requires temperatures between $150^{\circ}$ and $200^{\circ} \mathrm{C}$ (Seyfried and Bischoff, 1979; Bischoff and Seyfried, 1978). Increased temperature and $\mathrm{Ca}$ concentration on subsequent legs resulted in monotonic decreases in $\mathrm{SO}_{4}$ concentration as the hole was deepened. Sodium is removed in greater amounts as the maximum borehole temperatures increase (Fig. 7D). Potassium, on the other hand, appears to be removed in lesser quantities as the borehole temperature rises (Fig. 7E).

Oxygen isotopes show a trend between Legs 111 and 137 in agreement with this argument (Fig 7F). The $\delta^{18} \mathrm{O}$ values from Leg 92 are quite scattered and are most likely affected by the large amount of bentonite left in the borehole following Leg 83 (Gieskes et al., 1986). The oxygen isotopes from Leg 111 extrapolate to a value of between $-1.3 \%$ and $-1.8 \%$, lower than the $-0.41 \%$ for Leg 137 . Since fractionation of ${ }^{18} \mathrm{O}$ between fluid and rock decreases as temperature increases, one would expect a lower value of $\delta^{18} \mathrm{O}$ for fluids from a lower temperature environment. Assuming the same extent of reaction, calculation of the difference in equilibrium fractionation between basalt and water for Legs $111\left(\mathrm{~T}_{\max }=145^{\circ} \mathrm{C}\right)$ and $137\left(\mathrm{~T}_{\max }=\right.$ $\left.162^{\circ} \mathrm{C}\right)\left(1000 \ln \alpha=\delta^{18} \mathrm{O}_{\text {basalt }}-\delta^{18} \mathrm{O}_{\text {water }}=\Delta\right)$ yields values of 10.42 and 8.96 , respectively. Thus, if the $\delta^{18} \mathrm{O}$ of the altered basalt is assumed constant, we can predict that the endmember from Leg 111 would be approximately $1.3 \%$ lighter than that from Leg 137 as observed (Fig. 7F). The oxygen isotopic evidence and comparison to theoretical fractionation support the concept that the reacted fluid originates at the hole bottom.

The regular changes in the reacted fluid "endmember" between legs (Fig. 7A-F), summarized in Table 5, can be interpreted as the result of reaction in the rubble pile at increasing temperatures as the borehole has been deepened between drilling legs. Alteration of the basalt releases $\mathrm{Ca}$ as $\mathrm{Mg}$-rich clays and chlorite are formed. This reaction scheme would produce an increase in $\mathrm{Ca}^{*}$ equivalent to the decrease in $\mathrm{Mg}$. This 1:1 Ca increase to $\mathrm{Mg}$ decrease is observed on Leg 70 , but on subsequent legs excess $\mathrm{Ca}$ is released relative to $\mathrm{Mg}$ consumed. This charge imbalance is made up for by removal of $\mathrm{Na}$ from the borehole fluids. $\mathrm{Na}$ is presumably removed into albite or at lower temperatures analcime or other Na-zeolites, replacing the anorthic plagioclase of fresh basalt. Surprisingly few experimental investigations have shown $\mathrm{Na}$ removal from solution during seawater/basalt interaction. However, many experiments have shown definitive formation of albite by observation of the reacted solids (e.g., Mottl and Holland, 1978). The majority of these experiments have been performed at water/rock mass ratios near 5 , and temperatures $\geq 300^{\circ} \mathrm{C}$. Perhaps a lower $\mathrm{w} / \mathrm{r}$ and temperature are necessary for albitization to occur. Based on observations of seafloor metabasalts, Mottl (1983) suggests that albitization occurs only in strongly rock-dominated sys- 
Table 5. Comparison of borehole fluid endmembers at $\mathrm{Mg}=0 \mathrm{mM}$ for Hole 504B borehole fluids.

\begin{tabular}{|c|c|c|c|c|c|c|}
\hline Leg & $\begin{array}{l}\text { Depth } \\
\text { (mbsf) }\end{array}$ & $\begin{array}{l}\text { Temp. } \\
\left({ }^{\circ} \mathrm{C}\right)\end{array}$ & $\underset{(\mathrm{mM})}{\mathrm{Mg}}$ & $\underset{(\mathrm{mM})}{\mathrm{Na}}$ & $\begin{array}{l}\mathrm{Ca}^{*} \\
(\mathrm{mM})\end{array}$ & $\underset{(\mathrm{mM})}{\mathrm{K}}$ \\
\hline 70 & 489 & 80 & 0 & - & 65.0 & - \\
\hline 83 & 836 & 112 & 0 & 421 & 98.2 & 3.9 \\
\hline $92 / 111$ & 1350 & 145 & 0 & 380 & 104.0 & 5.2 \\
\hline 137 & 1562 & 162 & 0 & 337 & 120.0 & 6.2 \\
\hline \multirow{2}{*}{\multicolumn{3}{|c|}{$\begin{array}{l}\text { Seawater } \\
\text { Mottl \& Gieskes 83-111 }\end{array}$}} & 53.4 & 475 & 10.45 & 10.4 \\
\hline & & & 0 & 400 & & 4.5 \\
\hline
\end{tabular}

Note: $-=$ not analyzed

tems. Sodium uptake on the order of that observed in Hole 504B has been observed in one water/rock experiment at high temperature and low water/rock ratio $\left(\mathrm{T}=300^{\circ} \mathrm{C}, \mathrm{w} / \mathrm{r}=1\right.$; Mottl and Holland, 1978). Theoretical calculations of Seyfried (1987), suggest that $\mathrm{Na}$ is not removed from solution at high temperature $\left(>300^{\circ} \mathrm{C}\right)$ due to enhanced stability of epidote solid solutions resulting in redistribution of $\mathrm{Ca}$ in the solid phases. At lower temperatures, however, the stability of epidote decreases, while that of albite increases. Competition between albite and epidote for the $\mathrm{Si}$ and $\mathrm{Al}$ mobilized during alteration of plagioclase would thus seem to favor formation of albite at lower tem- peratures. Mass balance calculations in the previous section also sup- port precipitation of albite or analcime as the sink for $\mathrm{Na}$ from the fluids. Uptake of $\mathrm{K}$, while not of major importance to the charge bal- ance, decreases as the maximum borehole temperature increases. Experimental evidence suggests that $\mathrm{K}$ should be released at temperatures above $150^{\circ} \mathrm{C}$, while taken up at low temperatures (Mottl, 1983). The direction of change in $\mathrm{K}$ is in agreement with this transition, but the temperature of the borehole during Leg 137 is slightly higher than would be expected for continued uptake of $\mathrm{K}$. This is perhaps due to the relatively low percentage of rock altered as calculated above; hence, relatively little $\mathrm{K}$ is released in comparison to experiments run on very fine grain material where all the $\mathrm{K}$ is mobilized.

\section{SUMMARY}

Borehole fluids sampled during Leg 137 were analyzed for major, minor, and isotopic composition for various elements. Changes in fluid chemistry reflect the result of seawater/basalt interaction. Element vs. element diagrams reveal that the fluid samples can be described as mixtures between a single reacted fluid component and seawater. Clay-coated basaltic rubble and anhydrite collected from the borehole prior to drilling suggest the possibility of reaction occurring within the borehole itself. $\mathrm{Sr}$ and $\mathrm{Li}$ isotopic investigations reveal a low w/r ratio and incomplete mobilization of $\mathrm{Sr}$ from the basalt, suggesting incomplete reaction of fresh basalt in the reaction zone. Comparison of the borehole fluid endmembers between drilling legs reveals a regular change in chemistry as the borehole temperatures increase. Combined, this information suggests that reaction in the rubble and not true formation fluid is responsible for the observed changes in borehole fluid chemistry.

Important information of the nature of exchange at intermediate temperatures has nonetheless been gained through this study. A sink for sodium during reaction between seawater and basalt at temperatures of $80^{\circ} \mathrm{C}$ to at least $162^{\circ} \mathrm{C}$ has been observed. Chemical exchange between seawater and the crust at these temperatures may not be limited to removal of anhydrite and seawater $\mathrm{Sr}$ as some simple models of axial hydrothermal systems might suggest. Results from this study imply that significant reactions in the recharge zones of hydrothermal systems can occur as the fluids heat up in contact with basalt. Similarly, reaction of seawater with cooling basalts on the flanks of the mid-ocean ridges may result in significant fluxes of $\mathrm{Na}$, an element elusive to flux calculations due to its high concentration in seawater. $\mathrm{Li}$ was found to be leached at moderate $\left(160^{\circ} \mathrm{C}\right)$ borehole temperatures, with some redistribution into solid phases. The bore-
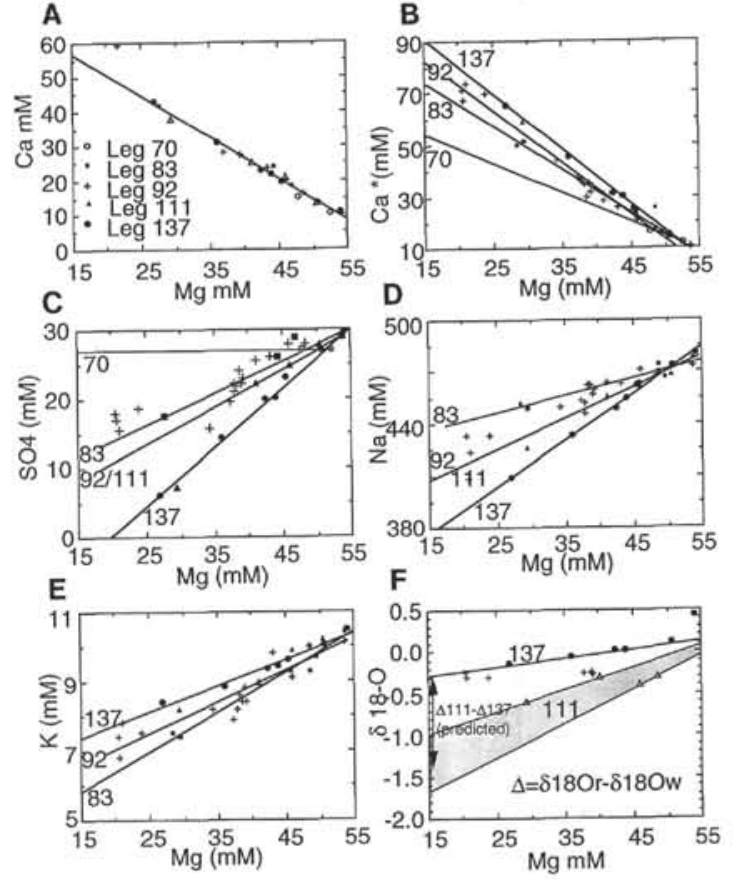

Figure 7. Comparison of element vs. $\mathrm{Mg}$ mixing lines for all legs from Hole 504B. Data from previous legs are from Mottl et al. (1985), Gieskes et al. (1986), and Shipboard Scientific Party (1988).

hole sampling program in Hole 504B has provided an in-situ basalt/ seawater experiment, which has evolved as the hole has been drilled deeper into the hotter formation.

\section{ACKNOWLEDGMENTS}

This work was supported by a grant from JOI-USSAC. The authors are grateful to David Janecky for providing anhydrite solubility calculations. Thorough reviews by Michael Mottl and Michael Berndt helped to improve this paper significantly.

\section{REFERENCES}

Alt, J.C., Anderson, T.F., Bonnell, L., and Muehlenbachs, K., 1989. Mineralogy, chemistry, and stable isotopic compositions of hydrothermally altered sheeted dikes: ODP Hole 504B, Leg 111. In Becker, K., Sakai, H., et al., Proc. ODP, Sci. Results, 111: College Station, TX (Ocean Drilling Program), $27-40$.

Alt, J.C., and Honnorez, J., 1984. Alteration of the upper oceanic crust, DSDP Site 417: mineralogy and chemistry. Contrib. Mineral. Petrol., 87:149-169.

Alt, J.C., Honnorez, J., Laverne, C., and Emmermann, R., 1986. Hydrothermal alteration of a $1 \mathrm{~km}$ section through the upper oceanic crust, Deep Sea Drilling Project Hole 504B: mineralogy, chemistry, and evolution of seawater-basalt interactions. J. Geophys. Res., 91:10309-10335.

Anderson, R.N., Langseth, M.G., and Sclater, J.G., 1977. The mechanisms of heat transfer through the floor of the Indian Ocean. J. Geophys. Res., 82:3391-3409.

Baker, P.A., Stout, P.M., Kastner, M., and Elderfield, H., 1991. Large-scale lateral advection of seawater through oceanic crust in the central equatorial Pacific. Earth Planet. Sci. Lett., 105:522-533.

Berger, G., Schott, J., and Guy, C., 1988. Behavior of Li, Rb, and Cs during basalt glass and olivine dissolution and chlorite, smectite and zeolite precipitation from seawater: experimental investigations and modelization between $50^{\circ} \mathrm{C}$ and $300^{\circ} \mathrm{C}$. Chem. Geol., 71:297-312.

Berndt, M.E., and Seyfried, W.E., Jr., 1986. B, Li, and associated trace element chemistry of alteration minerals, Holes 597B and 597C. In Leinen, M.,

\footnotetext{
Abbreviations for names of organizations and publications in ODP reference lists follow the style given in Chemical Abstracts Service Source Index (published by American Chemical Society).
} 
Rea, D.K., et al., Init. Repts. DSDP, 92: Washington (U.S. Govt. Printing Office.), 491-498.

Berndt, M.E., Seyfried, W.E., and Beck, J.W., 1988. Hydrothermal alteration processes at mid-ocean ridges: experimental and theoretical constraints from $\mathrm{Ca}$ and $\mathrm{Sr}$ exchange reactions and $\mathrm{Sr}$ isotopic ratios. J. Geophys. Res., 93:4573-4583.

Bischoff, J.L., and Seyfried, W.E., 1978. Hydrothermal chemistry of seawater from $25^{\circ} \mathrm{C}$ to $350^{\circ} \mathrm{C}$. Am. J. Sci., 278:838-860.

Böhlke, J.K., Alt, J.C., and Muehlenbachs, K., 1984. Oxygen isotope-water relations in altered deep-sea basalts: low temperature mineralogical controls. Can. J. Earth Sci., 21:67-77.

Chan, L.H., 1987. Lithium isotope analysis by thermal ionization mass spectrometry of lithium metaborate. Anal. Chem., 59:2662-2665.

Chan, L.H., and Edmond, J.M., 1988. Variation in the lithium isotope composition in the marine environment. Geochim. Cosmochim. Acta, 52:1711-1717.

Chan, L.H., Edmond, J.M., Tompson, G., and Gillis, K., 1992. Lithium isotopic composition of submarine basalts: implications for the lithium cycle in the oceans. Earth Planet. Sci. Lett., 108:151-160.

Cole, D.R., Mottl, M.J., and Ohmoto, H., 1987. Isotopic exchange in mineralfluid systems. II. Oxygen and hydrogen isotopic investigation of the experimental basalt-seawater system. Geochim. Cosmochim. Acta, 51:1523-1538.

Elderfield, H., and Greaves, M.J., 1981. Strontium isotope geochemistry of Icelandic geothermal systems and implications for seawater chemistry. Geochim. Cosmochim. Acta, 45:2201-2212.

Fisher, A.T., Becker, K., Narasimhan, T.N., Langseth, M.G., and Mottl, M.J., 1990. Passive, off-axis convection through the southern flank of the Costa Rica rift. J. Geophys. Res., 95:9343-9370.

Gieskes, J.M., Gamo, T., and Brumsack, H.J., 1991. Chemical methods for interstitial water analysis aboard JOIDES Resolution. ODP Tech. Note, 15.

Gieskes, J.M., Kastner, M., Erzinger, J., and Boulegue, J., 1986. Geochemical studies in Hole 504B, Leg 92. In Leinen, M., Rea, D.K., et al. Init. Repts. DSDP, 92: Washington (U.S. Govt. Printing Office), 547-562.

Gieskes, J.M., and Magenheim, A.J., 1992. Borehole fluid chemistry of DSDP Hole 395A and 534A results from operation Dianaut. Geophys. Res. Lett., 19:513-516.

Gieskes, J.M., and Peretsman, G., 1986. Water chemistry procedures aboard JOIDES Resolution-some comments. ODP Tech. Note, 5.

Hess, J., Bender, M., and Schilling, J.-G., 1991. Assessing seawater/basalt exchange of strontium isotopes in hydrothermal processes on the flanks of mid-ocean ridges. Earth Planet. Sci. Lett., 103:133-142.

Hey, M.H., 1954. A new review of the chlorites. Mineral. Mag., 30:277.

Holland, H.D., 1978. The Chemistry of the Atmosphere and Oceans: New York (Wiley).

Holser, W.T., and Kaplan, I.R., 1966. Isotope geochemistry of sedimentary sulfate. Chem. Geol., 1:93-135.

Ishikawa, T., and Nakamura, E., 1992. Boron and boron isotope geochemistry of the oceanic crust from DSDP Hole 504B. Geochim. Cosmochim. Acta, 56:1633-1639.

Langseth, M.G., Mottl, M.J., Hobart, M.A., and Fisher, A., 1988. The distribution of geothermal and geochemical gradients near Site 501/504: implications for hydrothermal circulation in the oceanic crust. In Becker, K., Sakai, H., et al., Proc. ODP, Init. Repts., 111: College Station, TX (Ocean Drilling Program), 23-32.

Magenheim, A.J., 1989. Hydrothermal alteration in near surface sediments of the Guaymas Basin, Gulf of California and the Escanaba Trough, Gorda Ridge [M.S. thesis]. Univ. California San Diego.

Magenheim, A.J., Bayhurst, G., Alt, J.C., and Gieskes, J.M., 1991. Borehole fluid chemistry in DSDP/ODP Hole 504B: an investigation of in situ water/rock reaction. Eos, 72:539.

1992. ODP Leg 137, borehole fluid chemistry in Hole 504B. Geophys. Res. Lett., 19:521-524.

Marchig, V., Erzinger, J., and Heinze, P.M., 1986. Sediment in the black smoker area of the East Pacific Rise $\left(18.5^{\circ}\right.$ S). Earth Planet. Sci. Lett., 79:93-106.

Mazor, E., 1992. Interpretation of water-rock interactions in cases of mixing and undersaturation. In Karaka, Y.K., and Maest, A.S. (Eds.), Water-Rock Interaction: WRI-7: Proc. 7th Int. Symp. Water-Rock Interaction: Rotterdam (A.A. Balkema), 233-236.

Mengel, K., and Hoefs, J., 1990. Li- $\delta^{18} \mathrm{O}-\mathrm{SiO}_{2}$ systematics in volcanic rocks and mafic lower crustal granulite xenoliths. Earth Planet. Sci. Lett. 101:42-53.
Michard, A., 1989. Rare earth element systematics in hydrothermal fluids. Geochim. Cosmochim. Acta, 53:745-750.

Mottl, M.J., 1983. Metabasalts, axial hot springs, and structure of hydrothermal systems at mid-ocean ridges. Geol. Soc. Am. Bull., 94:161-180.

Mottl, M.J., Druffel, E.R.M., Hart, S.R., Lawrence, J.R., and Saltzman, E.S., 1985. Chemistry of hot waters sampled from basaltic basement in Hole 504B, Deep Sea Drilling Project Leg 83, Costa Rica Rift. In Anderson, R.N., Honnorez, J., et al., Init. Repts. DSDP, 83: Washington (U.S. Govt. Printing Office), 315-328.

Mottl, M.J., and Gieskes, J.M., 1990. Chemistry of waters sampled from oceanic basement boreholes, 1979-1988. J. Geophys. Res., 95:9327-9342.

Mottl, M.J., and Holland, H.D., 1978. Chemical exchange during hydrothermal alteration of basalt by seawater. I. Experimental results for major and minor components of seawater. Geochim. Cosmochim. Acta, 42:1103-1115.

Nakamura, E., Ishikawa, T., Birck, J.-L., and Allègre, C.J., 1992. Precise boron isotopic analyses of natural rock samples using a boron-mannitol complex. Chem. Geo., 94:193-204

Pezard, P., 1990. Electrical properties of mid-ocean ridge basalt and implications for the structure of the upper oceanic crust in Hole 504B. J. Geophys. Res., 95:9237-9264.

Ryan, J.G., and Langmuir, C.H., 1987. The systematics of lithium abundances in young volcanic rocks. Geochim. Cosmochim. Acta, 51:1727-1741.

Seyfried, W.E., Jr., 1987. Experimental and theoretical constraints on hydrothermal alteration processes at mid-ocean ridges. Annu. Rev. Earth Planet. Sci., 15:317-335.

Seyfried, W.E.. Jr., and Bischoff, J.L., 1979. Low temperature basalt alteration by seawater: an experimental study at $70^{\circ} \mathrm{C}$ and $150^{\circ} \mathrm{C}$. Geochim. Cosmochim. Acta, 43:1937-1947.

Seyfried, W.E., Jr., Janecky, D.R., and Mottl, M.J., 1984. Alteration of the oceanic crust: implications for the geochemical cycles of B and Li. Geochim. Cosmochim. Acta, 48:557-569.

Shimizu, H., Mori, K., and Masuda, A., 1989. REE, Ba, and Sr abundances and $\mathrm{Sr}, \mathrm{Nd}$, and $\mathrm{Ce}$ isotopic ratios in Hole 504B basalts, ODP Leg 111, Costa Rica Rift. In Becker, K., Sakai, H., et al., Proc. ODP, Sci. Results, 111: College Station, TX (Ocean Drilling Program), 77-83.

Shipboard Scientific Party, 1988. Site 504: Costa Rica Rift. In Becker, K., Sakai, H., et al., Proc. ODP, Init. Repts., 111: College Station, TX (Ocean Drilling Program), 35-251 , 1992a. Site 504. In Becker, K., Foss, G., et al., Proc. ODP, Init. Repts., 137: College Station, TX (Ocean Drilling Program), 15-55.

, 1992b. Site 504. In Dick, H.J.B., Erzinger, J., Stokking, L.B., et al., Proc. ODP, Init. Repts., 140: College Station, TX (Ocean Drilling Program), 37-200.

Sholkovitz, E.R., Piepgras, D.J., and Jacobsen, S.B., 1989. The pore-water chemistry of rare earth elements in Buzzards Bay sediments. Geochim. Cosmochim. Acta, 53:2847-2856.

Spivack, A.J., and Edmond, J.M., 1986. Determination of boron isotope ratio by thermal ionization mass spectroscopy of the dicesium metaborate cation. Anal. Chem., 51:1033-1043.

Staudigel, H., and Hart, S.R., 1983. Alteration of basaltic glass: mechanisms and significance of the oceanic crust-seawater budget. Geochim. Cosmochim. Acta, 47:337-350.

Sun, S.-S., and McDonough, W.F., 1989. Chemical and isotopic systematics of oceanic basalts: implications for mantle composition and processes. In Saunders, A.D., and Norry, M.J. (Eds.), Magmatism in the Ocean Basins. Geol. Soc. Spec. Publ. London, 42:313-345.

Totland, M., Jarvis, I., and Jarvis, K.E., 1992. An assessment of dissolution techniques for the analysis of geological samples by plasma spectrometry. Chem. Geol., 95:35-62.

Von Damm, K.L., 1990. Seafloor hydrothermal activity: black smoker chemistry and chimneys. Annu. Rev. Earth Planet. Sci., 18:173-204.

Von Damm, K.L., Edmond, J.M., Grant, B., Measures, C.I., Walden, B., and Weiss, R.F., 1985. Chemistry of submarine hydrothermal solutions at $21^{\circ}$ N, East Pacific Rise. Geochim. Cosmochim. Acta, 49:2197-2220.

Zuleger, E., and Erzinger, J., 1988. Determination of the REE and Y in silicate materials with ICP-AES. Fresenius' Z. Anal. Chem., 332:140-143.

Date of initial receipt: 14 April 1993

Date of acceptance: 14 April 1994

Ms 137/140SR-024 